\title{
High-resolution stratigraphy of the Cenomanian-Turonian boundary interval at Pueblo (USA) and wadi Bahloul (Tunisia): stable isotope and bio-events correlation
}

\section{Stratigraphie à haute résolution de la limite Cénomanien-Turonien sur les coupes de Pueblo (États-Unis) et de l'Oued Bahloul (Tunisie) : isotopes stables et corrélation des événements biologiques}

\author{
Michèle Caron ${ }^{\mathrm{a}, *}$, Stephan Dall'Agnolo ${ }^{\mathrm{a}}$, Hugues Accarie ${ }^{\mathrm{b}}$, Enriqueta Barrera ${ }^{\mathrm{c}}$, \\ Erle G. Kauffman ${ }^{\mathrm{d}}$, Francis Amédro ${ }^{\mathrm{e}}$, Francis Robaszynski ${ }^{\mathrm{f}}$ \\ a Département de Geosciences, Institut de Géologie, Université de Fribourg, Pérolles, 1700 Fribourg, Switzerland \\ b École des Mines de Paris, 35, rue Saint-Honoré, 77305 Fontainebleau, France \\ c National Science Foundation, 4201 Wilson Boulevard, Arlington VA 22230, USA \\ d Department of Geological Sciences, Indiana University, Bloomington IN 47405, USA \\ e 26, rue de Nottingham, 62100 Calais, France \\ ${ }^{\mathrm{f}}$ Faculté Polytechnique, 9, rue de Houdain, 7000 Mons, Belgium
}

Received 23 February 2004; accepted 26 November 2004

\section{Abstract}

A high-resolution stratigraphy has been developed for the interval encompassing the Cenomanian-Turonian boundary (CTBI), by means of several lithological, biological and geochemical events. This work entails the study of two sections selected on the base of the completeness of their sedimentary record and their contrasting paleogeographical setting: (1) The Rock Canyon Anticline section west of Pueblo, Colorado, (US Western Interior Basin), which is the Global Boundary Stratotype Section and Point (GSSP) candidate for the base of the Turonian stage, as well as the reference section for the ammonite biostratigraphy of the CTBI; and (2) The wadi Bahloul section in Central Tunisia which is the best and complete section spanning this time interval in the southern Tethyan Margin. These sections record similar biogeochemical events that can be correlated over a great distance.

Several important biological and geochemical events determined in these sections relative to the ammonite zonation of the CTBI are listed below in chronological order from old to young: 1. FO (first occurrence) of Sciponoceras gracile-Metoicoceras geslinianum ammonite Assemblage-Zone, 2. $\delta^{13} \mathrm{C}$ peak I, 3. LO (last occurrence) of Rotalipora cushmani, 4. "Heterohelix shift", 5. FO of the ammonites Pseudaspidoceras pseudonodosoides and Neocardioceras juddii, 6. $\delta^{13} \mathrm{C}$ peak II, 7. $\delta^{13} \mathrm{C}$ peak III, 8. LO of Cenomanian ammonites (Ps. pseudonodosoides and N. juddii), 9. LO of Anaticinella, 10. FO of Turonian ammonites (Watinoceras devonense, base of the Turonian stage), 11. "filament event", 12. FO of Pseudaspidoceras flexuosum, 13. FO of the Tethyan Helvetoglobotruncana helvetica, 14. FO of Mammites nodosoides, 15. FO of the Western Interior H. helvetica.

In the two sections, the Cenomanian-Turonian $(\mathrm{C} / \mathrm{T})$ boundary, as defined by the ammonite biostratigraphy, is placed within an interval about $50 \mathrm{~cm}$ thick. This interval is termed here as the C/T boundary "precision interval". The $\delta^{13} \mathrm{C}$ peak III slightly precedes the precision interval. The genus Anaticinella planktic foraminifer disappears in the middle part of this interval. The "filament event" occurs just above it and is coeval with the first occurrence of Turonian ammonites. These events are useful for placing the $\mathrm{C} / \mathrm{T}$ boundary precision interval in absence of ammonite markers. 
Comparing ammonite and planktic foraminiferal biostratigraphy we have dated and correlated changes occurring in planktic foraminiferal assemblages. On this base, as an important result, we have demonstrated the diachroneity of the FO of Helvetoglobotruncana helvetica and the variable duration of the Whiteinella archaeocretacea PRZ.

\section{Résumé}

Une stratigraphie à haute résolution, pour l'intervalle de passage du Cénomanien au Turonien, a été établie sur la base de niveaux-repères correspondant à plusieurs événements lithologiques, biologiques et géochimiques.

Deux sites représentatifs de cette période à l'échelle globale ont été sélectionnés pour la richesse de leur enregistrement sédimentaire et pour le contraste de leur position paléogéographique : (1) la coupe de Rock Canyon Anticline, à l'ouest de Pueblo, Colorado (Bassin du Western Interior, USA), candidat GSSP pour la base de l'étage Turonien, qui offre la référence indispensable, c'est-à-dire la trame biostratigraphique par les ammonites ; (2) la coupe de l'oued Bahloul en Tunisie centrale, la plus représentative sur la marge sud de la Téthys. Les corrélations établies entre ces deux coupes permettent une stratigraphie à très haute résolution malgré les grandes distances qui les séparent.

Les événements répertoriés dans cette étude ont été classés par ordre d'apparition chronologique et positionnés par rapport aux zones d'ammonites (datation relative) : (1) l'apparition de Sciponoceras gracile-Metoicoceras geslinianum ammonite Assemblage-Zone, (2) le pic I $\delta^{13} \mathrm{C}$, (3) la dernière Rotalipora cushmani, (4) le « shift » des Heterohelix, (5) l'apparition des ammonites Pseudaspidoceras pseudonodosoides et Neocardioceras juddii, (6) le pic II $\delta^{13} \mathrm{C}$, (7) le pic III $\delta^{13} \mathrm{C}$, (8) les dernières ammonites du Cénomanien (Ps. pseudonodosoides et N. juddii), (9) les dernières Anaticinella, (10) les premières ammonites du Turonien (Watinoceras devonense, base de l'étage Turonien), (11) la réapparition en masse des «filaments », (12) l'apparition de Pseudaspidoceras flexuosum, (13) l'apparition de Helvetoglobotruncana helvetica dans la Téthys, (14) l'apparition de Mammites nodosoides, (15) les premières H. helvetica dans le Bassin du Western Interior.

La limite $\mathrm{C} / \mathrm{T}$, telle qu'elle est définie par la distribution des ammonites repères (entre les événements 8 et 10) est comprise dans un intervalle de $50 \mathrm{~cm}$ environ sur les deux sites. Cet intervalle est appelé ici « intervalle de précision » de la limite $\mathrm{C} / \mathrm{T}$. Le pic III $\delta^{13} \mathrm{C}$ précède de peu cet intervalle de précision. Le genre Anaticinella, foraminifère planctonique, disparaît au milieu de cet intervalle et la réapparition en masse des « filaments » arrive juste au-dessus de l'intervalle, en même temps que la première ammonite turonienne. Chacun de ces événements peut être utilisé pour placer l'intervalle de précision de la limite $\mathrm{C} / \mathrm{T}$ sur les coupes où les ammonites repères sont absentes.

De plus, les corrélations établies dans cette étude entre les biozones d'ammonites et de foraminifères planctoniques ont permis de dater les changements au sein des populations de foraminifères planctoniques. Une des conclusions majeures de cette stratigraphie à haute résolution est l'évidence de la diachronie à l'échelle globale de l'apparition de Helvetotruncana helvetica, foraminifère planctonique réputé jusqu'ici excellent marqueur et, en conséquence, la zone partielle à Whiteinella archaeocretacea peut avoir une durée variable.

Keywords: Cenomanian-Turonian; Stable isotopes; Ammonites; Planktic foraminifera; Bioevents; Biostratigraphy

Mots clés : Cénomanien-Turonien ; Isotopes stables ; Ammonites ; Foraminifères planctoniques ; Événements biologiques ; Biostratigraphie

\section{Introduction}

Numerous studies have focused on the Cenomanian-Turonian boundary interval (CTBI), and a variety of depositional and climatic models have been proposed to explain the anomalous high organic carbon accumulation which occurred at this time worldwide. This deposition of organic rich sediments has been interpreted to reflect an oceanic anoxic event, the second (OAE2) of the Cretaceous (Schlanger and Jenkyns, 1976). To better understand the events associated with this half million to one million-year transition interval (Caron et al., 1999) a highresolution multiproxy stratigraphy has been applied to provide precise datum levels that can be correlated globally. To achieve this goal, two sections (Fig. 1) were selected on the base of their very different paleogeographic location and the completeness of their sedimentary record: The Pueblo section in Colorado that was deposited in the Western Interior Seaway (WIS) of North America, and is the stratotype for the base of the Turonian; and wadi Bahloul section in central Tunisia, which best represents the CTBI in the southern margin of the Tethys. Despite regional differences in paleogeographic and tectonic settings, global eustatic sea-level changes and oceanic paleoenvironmental events, the CTBI is similarly recorded in these sediments.
We combine results from ammonite and planktic foraminiferal biostratigraphy to identify significant datum levels, allowing the correlation between the Tethys and the WIS. The carbon isotope $\left(\delta^{13} \mathrm{C}\right)$ record was used to support the biostratigraphic correlation. In summary, aims of this study is to prove the tentative correlation between Northern Africa and the WIS proposed by Accarie et al. (1996) and finally to provide a framework to correlate multiple events at global scale.

\section{Geologic and paleogeographic setting (Fig. 1)}

The Rock Canyon Anticline section near Pueblo, Colorado, is situated in the central part of the Western Interior Basin (for the location of the section see Fig. 1 in Kennedy et al., 2000). The Cretaceous Western Interior Basin is a foreland basin, extending from the Gulf of Mexico, northward to the Arctic Ocean. The north-south elongation of the basin was extended by seaways. A southern prolongation connected the WIS to the northern Atlantic Ocean. The sediments deposited during this period recorded the contrasting effect of: (1) normal saline and warm marine Tethyan waters, incoming from the southern margin of the WIS; (2) cold and dense currents, flowing south from the northern Boreal portion of the seaway; and (3) lateral 


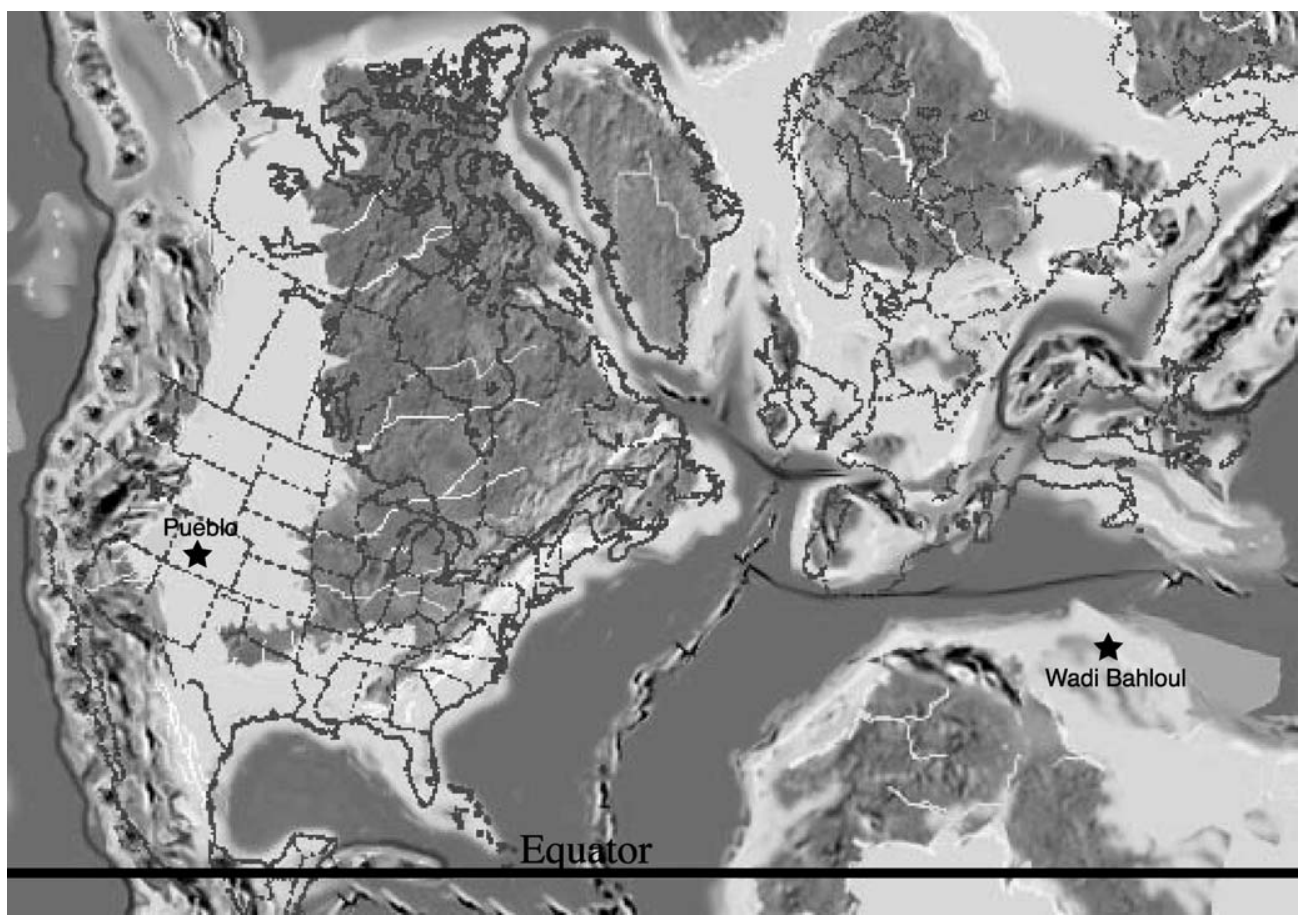

Fig. 1. Paleogeographic map showing the section at the Rock Canyon Anticline, west of Pueblo, Colorado, in the Western Interior Basin and the wadi Bahloul section in Central Tunisia, on the Southern Tethyan Margin. Late Cenomanian paleogeographic map reproduced from ODP site www.http://www.osdn.de.

Fig. 1. Carte paléogéographique montrant la coupe de Rock Canyon Anticline, à l'ouest de Pueblo, Colorado, dans le Bassin du Western Interior, et la coupe de l'oued Bahloul en Tunisie centrale, sur la marge sud de la Téthys. Carte paléogéographique reproduite à partir du site ODP www.http://www.osdn.de

runoff spreading as a surface layer of low salinity (Caldwell and Kauffman, 1993; West et al., 1998).

The wadi Bahloul section has been designated by Burollet et al. (1954) and Burollet (1956) as the type locality for the Bahloul Formation and dated late Cenomanian to early Turonian. These sediments were deposited in normal marine conditions on the outer shelf of the Tunisian platform. The wadi Bahloul outcrop offers the best record of the OAE2 in the southern margin of the Tethys, with organic-rich sediments and good preservation of ammonites, planktic foraminifera and other microfossils.

The wadi Bahloul and the Pueblo sections were thus deposited in two different oceanic settings. Therefore, this study provides insight on the $\mathrm{C} / \mathrm{T}$ global event under the influence of significantly different environmental factors.

\section{Biostratigraphic framework}

The C/T boundary (i.e., the base of the Turonian) has been historically placed within a time-envelope. As reported by Bengtson (1996: p. 71) in the Proceedings of the 2nd International Symposium on Cretaceous Stage Boundaries, “... in the standard ammonite zonation, the boundary should be chosen so as to fall within the interval between the top of the Metoicoceras geslinianum ammonite Zone and the base of the Mammites nodosoides ammonite Zone as used by Wright and Kennedy (1981)...” At the end of the 2nd International Symposium on Cretaceous Stage Boundaries, the Turonian Working Group proposed that the Pueblo section should be chosen as the Global Cenomanian-Turonian boundary stratotype section and the boundary pointed with the first occurrence (FO) of the ammonite Watinoceras devonense (Bengtson, 1996: p. 75). This level coincides with the base of bed 86 (nomenclature and numbering system of Cobban and Scott (1972), according to the current state of knowledge. These data adapted from Bengtson's Fig. 6 are reproduced in our Fig. 2, which shows the Pueblo lithologic column and the placement of the ammonites and planktic foraminiferal zones. Kennedy et al. (2000) have recently published a detailed synthesis of the CTBI ammonite distribution at Pueblo in support of the candidature of this section for the Global Boundary Stratotype.

While ammonites, by definition, can be used to define precisely the position of the $\mathrm{C} / \mathrm{T}$ boundary, changes in the planktic foraminiferal assemblages are less indicative and seem to occur over a broad interval of time coeval with the contemporary oceanic environmental perturbation. This planktic foraminiferal turnover corresponds to the traditional "zone à grosses globigérines" of Sigal (1977), defined as the Whiteinella archaeocretacea Partial Range Zone (PRZ) in Robaszynski and Caron (1995) (Fig. 2). According to Sigal (1977), the base of this turnover overlays the last occurrence (LO) of Rotalipora cushmani (top of the R. cushmani TRZ) and its top underlies the FO of Helvetoglobotruncana helvetica (base of the H. helvetica TRZ).

\section{Materials and methods}

This study was initiated by fieldwork at the outcrops, which were located using geologic maps. The study interval was identified based on the presence of key ammonites and planktic 


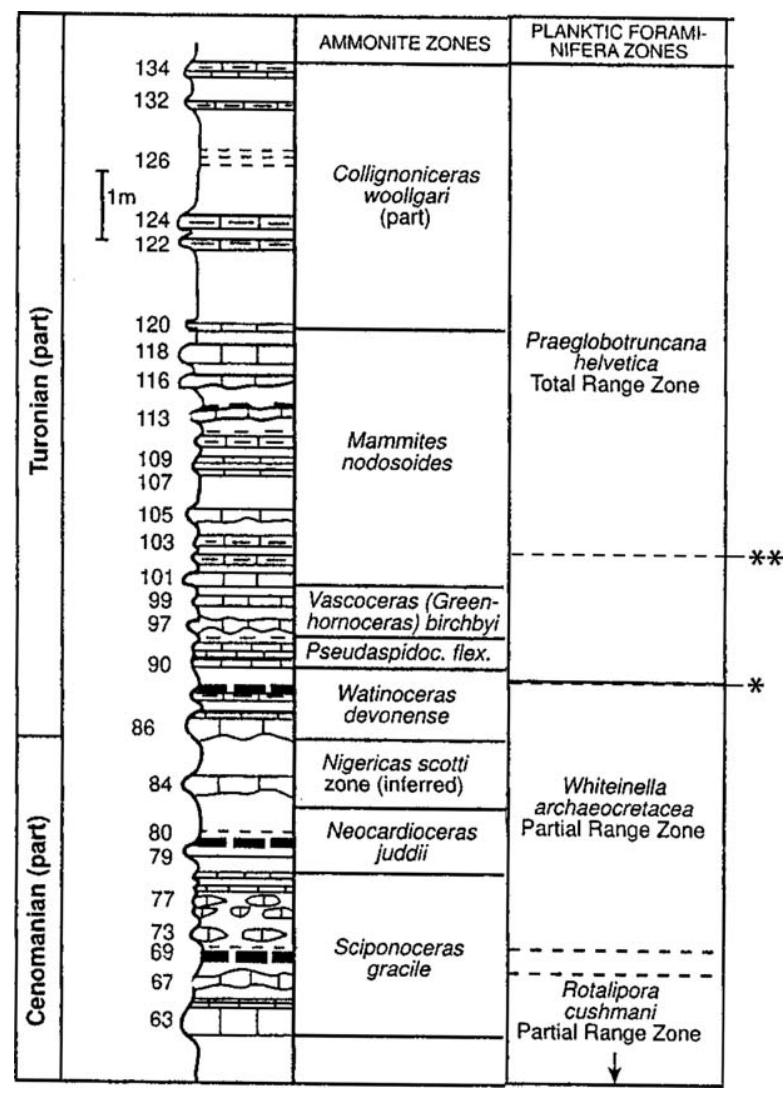

Fig. 2. Reproduction of Fig. 6 in Bengtson (1996) showing the section located west of Pueblo, Colorado, proposed as the Global Boundary Stratotype Section; and base of Bed 86 as the Cenomanian-Turonian Boundary Point (G.S.S.P). Ammonite zones are from Kennedy and Cobban (1991), and planktic foraminiferal zones are from Eicher and Diner (1985); * position of the FO of Helvetoglobotruncana helvetica according to Eicher and Diner (1985); ** position of the $\mathrm{FO}$ of $H$. helvetica as recorded in this study.

Fig. 2. Reproduction de la Fig. 6 de Bengston (1996) montrant la coupe située à l'ouest de Pueblo, Colorado, proposée comme coupe stratotypique de référence globale pour la limite Cénomanien-Turonien et la base du banc 86 proposée comme point limite (G.S.S.P.). Les zones d'ammonites sont tirées de Kennedy et Cobban (1991) et les zones de foraminifères planctoniques de Eicher et Diner (1985) ; * position de la première occurrence de Helvetoglobotruncana helvetica selon Eicher et Diner (1985); ** position de la première occurrence de $H$. helvetica selon la présente étude.

foraminiferal species. Both the Pueblo and wadi Bahloul sections were measured in detail. Closely spaced samples, across the entire planktic foraminiferal $W$. archaeocretacea Zone, were taken for studies by a multidisciplinary team of specialists. One hundred and sixty-six samples spanning $17 \mathrm{~m}$ of the Pueblo section and 99 samples spanning $50 \mathrm{~m}$ of the wadi Bahloul section were collected for a total of 264. Sample spacing averages $10 \mathrm{~cm}$ for the Pueblo section and $25 \mathrm{~cm}$ for the wadi Bahloul section. At Pueblo, foraminiferal preservation is relatively good in marly samples but degrades in limestone samples. In the wadi Bahloul section, foraminiferal preservation is good throughout the section. All samples were prepared in thin sections. Those samples consisting of marly sediment were also crushed and washed in a soap solution, followed by a final washing by ultrasounds.
All bulk sediment samples were analyzed for $\delta^{13} \mathrm{C}$ and $\delta^{18} \mathrm{O}$ isotopes, total organic carbon (TOC) content, and percentage of $\mathrm{CaCO}_{3}$. Analyses of TOC were performed in the laboratory of sedimentary geology at the University of Paris VI by F. Baudin. Measurements of $\mathrm{CaCO}_{3}$ percentage were performed at both the University of Fribourg (by S.D.) and the École des Mines de Paris (by H.A.). Stable isotopes were measured at the University of Bern using a VG Prism II ratio mass spectrometer equipped with a common acid bath $\left(\mathrm{H}_{3} \mathrm{PO}_{4}\right)$. Results are reported in permil (\%) deviation relative to the PDB reference standard. Standard error is $0.1 \%$ for $\delta^{18} \mathrm{O}$ and $0.05 \%$ for $\delta^{13} \mathrm{C}$.

\section{The Pueblo section}

The Pueblo section is one of the best-documented stage boundaries due to its dense faunal record, consisting mainly of ammonites, inoceramids, foraminifera and nannoplankton (Kennedy et al., 2000). Multiple descriptions exist for this locality (Cobban and Scott, 1972; Pratt and Threlkeld, 1984; Pratt, 1985; Elder and Kirkland, 1985). The lithological description presented here is based on detailed field observations, outcrop measurements and sampling by one of us (S.D.). Yet, for easy reading and comparison, the correlation of beds established by Cobban and Scott (1972) is used in Fig. 3, which shows our lithologic description of the section and its correspondence to those published by previous authors. This original bed numbering is also reproduced in Fig. $4 \mathrm{a}-\mathrm{c}$. In this study we will focus on a $10 \mathrm{~m}$ interval, from the top of the Hartland Shale Member to the upper part of the Bridge Creek Limestone Member, encompassing the CTBI. Our samples from Pueblo are identified by the letters "PB" followed by their location in meters within the section.

\subsection{Lithology (Figs. 4a and 5)}

\subsubsection{The Hartland Shale}

The upper Hartland Shale Member (PB $5 \mathrm{~m}$ to $\mathrm{PB} 0.3 \mathrm{~m}$ ) is composed predominantly of dark brown to black marlstones, containing thin lenticular, ripple-laminated, quartz-bearing calcarenite (marly limestone) beds. Numerous very thin - cm thick-layers of bentonite or limonite were also observed.

\subsubsection{The Bridge Creek Limestone}

The Bridge Creek Limestone lies in apparent conformability above the Hartland Shale. No evidence of erosion or scouring was observed at the base of the first bed (bed 63 after Cobban and Scott, 1972).

The most complete study is available in Elder and Kirkland (1985) who subdivided the Bridge Creek Limestone Member into five lithofacies. These are shales, marlstones, micritic limestones, calcarenites and bentonites. In a simplified way, the succession has been qualified as a rhythmical alternation of highly burrowed (Zoophycos, Thalassinoides, Planolites, Chondrites) limestone beds and microburrowed (Chondrites, "Planolites") to laminated marlstone beds (Savrda, 1998). Furthermore, the marly lithology consists of thin (cm thick) 
interbedded layers of marls and calcareous shales that in the weathered profile give the rock a platy aspect (beds 83,85 , Fig. 5(2)). These rhythmic couplets are disturbed by bentonites, discontinuities, and intervals of accentuated condensation (Meyers et al., 2001). A sharp contact is seen at PB $2 \mathrm{~m}$ (within bed 78), corresponding to a calcarenitic top on bed LS 5 of Elder (1985). After this level, the sedimentary record changes towards more rhythmic couplets. Several faint contacts are located between beds 90 and 97 (Fig. 5(1)). Highly burrowed limestone layers are frequent in this interval. Above bed 97, marlstone beds get thicker and limestone beds become more spaced out and calcarenitic, especially beginning at bed 105. The sediment record of the Bridge Crek Limestone is condensed, suggesting a low sedimentation rate (Elder and Kirkland, 1985: p. 131).

Differential diagenesis affected the series. Limestones apparently experienced more diagenetic alteration than the marlstones (Pratt, 1985; Ricken, 1993; Savrda, 1998). A great number of the limestone beds display evidence of dolomitization accompanied by weak pervasive silicification. Strong early diagenesis can be observed within lenticular beds 75 and 77 .

\subsection{Biostratigraphy}

\subsubsection{Ammonites}

The stratigraphic range of ammonites species in the Pueblo CTBI is well known owing to recent detailed publications of Cobban and Scott (1972), Cobban (1988), Kennedy and Cobban (1991), Kennedy et al. (1999), Kennedy et al. (2000). According to data from these authors, Fig. 4a summarizes the distribution of significant species in relation to the lithologic succession. The level notation is from Cobban and Scott (1972). Upsection, the ammonite zones are:

- Sciponoceras gracile Zone (from bed 63 up to the base of bed 78).

The assemblage at the base of this zone includes Calycoceras cf. naviculare (Mantell), Metoicoceras geslinianum (d'Orbigny) and Pseudocalycoceras angolaense (Spath). However, the index-species Sciponoceras gracile (Shumard) was found only in bed 67 . According to the assemblage, the $S$. gracile Zone is an Assemblage-Zone (AZ) equivalent to the Metoicoceras geslinianum Interval-Zone of the N-W Europe chalk (Wright and Kennedy, 1981) (Fig. 6). Another characteristic ammonite restricted to the $S$. gracile Zone is Euomphaloceras septemseriatum (Cragin), which is found from bed 67 up to bed 77.

- Neocardioceras juddii Zone (upper half of bed 78 up to bed 84).

The base of the zone coincides with the first occurrence of the index-species Neocardioceras juddii (Barrois and Guerne). Kennedy and Cobban (1991) referred one specimen in the upper half of bed 78. But this species is relatively common only in bed 79. According to Cobban et al. (1989) and Kennedy and Cobban (1991), the N. juddii Zone includes several other ammonite species restricted to this zone. These are Euomphaloceras costatum Cobban, Hook and Kennedy present in bed 79, and Pseudaspidoceras pseudonodosoides (Choffat).

- Watinoceras devonense Zone (from bed 86 up to bed 89).

The base of the zone is defined by the first occurrence of Watinoceras devonense that is the key stratigraphic marker for the lower boundary of the Turonian stage (Bengtson, 1996). At the Pueblo section, Watinoceras devonense occurs in bed 86 in association with Watinoceras praecursor Wright and Kennedy, $W$. depressum Wright and Kennedy, Quitmaniceras reaseri Powell, Allocrioceras larvatum (Conrad) and Hamites cimarronensis (Kauffman and Powell).

Bed 85, which is $63 \mathrm{~cm}$ thick, does not contain ammonites. Thus, it represents an undated interval between the top of the Neocardioceras juddii Zone of late Cenomanian age and the base of the Watinoceras devonense Zone of early Turonian age. Following Kennedy and Cobban (1991), it would correspond to the Nigericeras scotti Zone which is well represented in the Pritchett section, $170 \mathrm{~km}$ southeast of Pueblo. Hereafter, we will term this interval the $\mathrm{C} / \mathrm{T}$ precision interval. Possible future ammonite finding within bed 85 will clarify the age attribution of this level.

- Pseudaspidoceras flexuosum Zone (bed 90).

The base of the P. flexuosum Zone is placed by inference at the bottom of bed 90 owing to the presence of Vascoceras cf. proprium (Reyment), a species associated to P. flexuosum in the Texas area (Kennedy et al., 1987). Similar to the $S$. gracile Zone, the $P$. flexuosum Zone was conceived as an Assemblage-Zone by Kennedy and Cobban (1991). At present, Pseudaspidoceras flexuosum Powell has only been found in bed 97 at Pueblo, which has been placed in the next ammonite Zone Vascoceras birchbyi.

\subsubsection{Planktic foraminifera (Figs. $4 b, 7$ and 8)}

Beginning with the work of Eicher (1965), the foraminiferal biostratigraphy of the WIS has been studied in great detail (Eicher, 1969; Eicher and Worstell, 1970; Pratt et al., 1985; Caldwell et al., 1993; West et al., 1998; Leckie et al., 1998). In this study, the following foraminiferal zones of Robaszynski and Caron (1995) were identified with great accuracy:

- Upper part of Rotalipora cushmani TRZ (PB - $5.00 \mathrm{~m}$ to PB $0.50 \mathrm{~m}$ )

From the base of the studied section (PB $-5.00 \mathrm{~m})$ Rotalipora cushmani and $R$. greenhornensis are abundant and are associated with Praeglobotruncana gibba, Dicarinella algeriana, Anaticinella multiloculata and A. planoconvexa. This later taxon has been considered endemic to the Western Interior Basin (Eicher and Diner, 1985; see discussion in the Microfaunal events section, this paper). The LO of R. cushmani (PB $0.50 \mathrm{~m}$; middle of bed 68) is observed $20 \mathrm{~cm}$ above the LO of $R$. greenhornensis (PB $0.30 \mathrm{~m}$, bed 66) in the lower part of the ammonite Sciponoceras gracile Zone. Recently, Desmares et al. (2003) reported some specimens as " $R$. cushmani atypic" (according small 


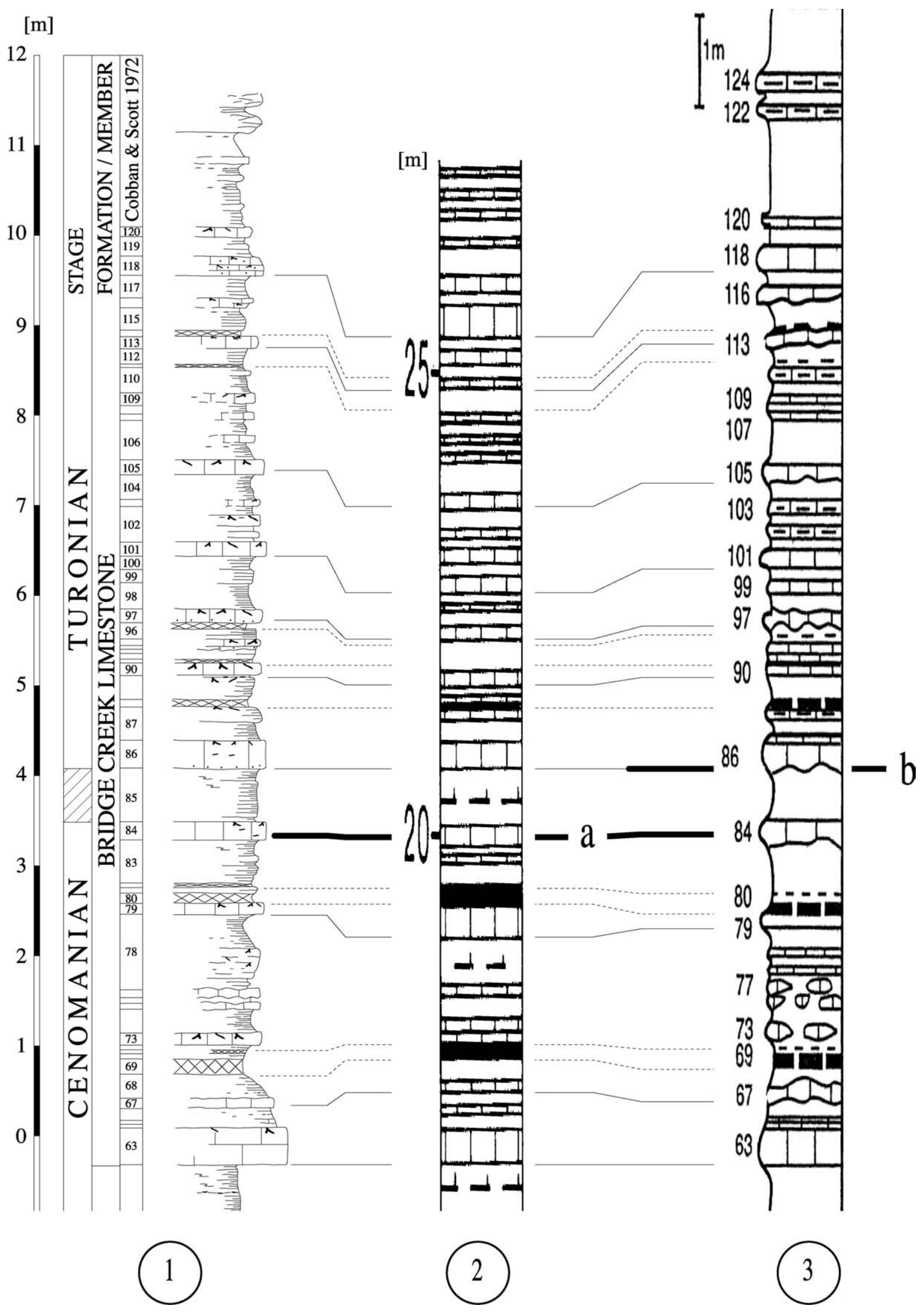


size and few chambers) in association with Anaticinella up to bed 85 at Pueblo section.

- Whiteinella archaeocretacea Partial Range Zone (PRZ) (PB $0.50 \mathrm{~m}$ to $\mathrm{PB} 6.75 \mathrm{~m}$ ).

In the Pueblo section, this zone spans the interval from the LO of R. cushmani in PB $0.50 \mathrm{~m}$ to the FO of H. helvetica in PB $6.75 \mathrm{~m}$ (bed 102), and extends from the middle of the $S$. gracile ammonite zone to the base of the Mammites nodosoides ammonite Zone. The foraminiferal assemblage is characterized by the proliferation of heterohelicids, hedbergellids and whiteinellids. The remarkably rapid increase in the relative abundance of heterohelicids at this level was first noted by Leckie (1985), and termed the "Heterohelix shift". Whiteinella archaeocretacea and W. praehelvetica are present throughout this zone. Specimens of Anaticinella planoconvexa were identified up to $\mathrm{PB} 3.85$ in bed 85 (within the $\mathrm{C} / \mathrm{T}$ precision interval).

- Helvetoglobotruncana helvetica TRZ (base of the zone at PB $6.75 \mathrm{~m})$.

We pointed the FO of H. helvetica at PB $6.75 \mathrm{~m}$ (bed 102), about $30 \mathrm{~cm}$ above the base of the Mammites nodosoides ammonite Zone (bed 101). This observation differs from that of previous authors (Eicher and Diner, 1985: p. 64; Kennedy et al., 2000: p. 305) and from a new information mentioned in Desmares et al. (2003). As no illustration is available from these publications (discussion below, this paper $\S 7.3 .6$ ), we maintain that the FO of $H$. helvetica is at the level PB $6.75 \mathrm{~m}$ where this species occurs associated with the keeled species (dicarinellids and marginotruncanids).

\subsection{Geochemistry (Fig. 4c)}

\subsubsection{Total organic carbon}

In the interval between the upper part of the Hartland Shale and the lower portion of the Bridge Creek Limestone that records the $\mathrm{C} / \mathrm{T}$ boundary, TOC values range between $0 \%$ and $6 \%$. Our results are comparable with previous ones (Pratt and Threlkeld, 1984; Pratt, 1985; Pratt et al., 1993). Overall, TOC values are low $(<1 \%)$ in the lower part of the section up to bed 77. A marked increase begins in bed 79 and reaches a maximum of $5 \%$ at the base of bed 85 . Then, values decrease to 0 $1 \%$ in the interval from bed 86 to bed 93 . From bed 94 to bed 100 , TOC values exceed $5 \%$. Above bed 100 , values decrease progressively.
The general trend described above is a function of the sediment type as well as sedimentary processes. Highly variable TOC values are linked to the presence of marl/limestone couplets, where laminated marls contain significant organic matter, and burrowed limestone beds contain negligible amounts of organic matter. Furthermore, the two intervals of low TOC content are associated with packages of alternating clastic limestones (inoceramid calcarenites) and marls with current associated sedimentary structures, whereas intervals of high TOC are characterized by calcispherites and highly laminated marls.

\subsubsection{Stable carbon isotopes}

Previous studies have shown a major positive $\delta^{13} \mathrm{C}$ excursion $(>2 \%$ ), spanning the Cenomanian-Turonian boundary at Pueblo (Pratt and Threlkeld, 1984; Pratt, 1985; Pratt et al., 1993). Our $\delta^{13} \mathrm{C}$ results, based on high-resolution sampling (5 to $20 \mathrm{~cm}$ ), show the excursion starting at $\mathrm{PB}-1.5 \mathrm{~m}$ and ending at PB $7.2 \mathrm{~m}$ (bed 104). They also reveal that the isotopic excursion can be subdivided into three major features (Fig. 4c). These are: a first positive peak (peak I, PB $0.2 \mathrm{~m}$ in bed 66), defining the beginning of a plateau; the end of this plateau (peak II, PB $2.85 \mathrm{~m}$ in bed 81) followed by a small trough; and the last positive peak before the long decline of values (peak III, PB $3.55 \mathrm{~m}$ in base of bed 85).

These features are also visible in the $\delta^{13} \mathrm{C}$ curve of Pratt (1985: Fig. 5). This author also described numerous $\delta^{13} \mathrm{C}$ fluctuations that correlate with lithology (Pratt, 1985; Pratt et al., 1993). In the highly bioturbated limestone, the signal is systematically shifted (by 0.5 to $2 \%$ ) towards more negative values than those in adjacent beds of marlstone or calcareous shale. This close relationship between $\delta^{13} \mathrm{C}$ and lithology is due to pervasive cementation during early diagenesis (Pratt, 1985; Pratt et al., 1993). According to this author, the $\delta^{13} \mathrm{C}$ signal is less overprinted in marls during cementation, and therefore it retains some of the primary isotopic signal. The present study confirms this result. All points showing diagenetic overprinting have been plotted separately in Fig. 4c (stipple curve) and will not be discussed further. These samples have also been highlighted in the curves for TOC and $\mathrm{CaCO}_{3}$ percentage.

The general features of the $\delta^{13} \mathrm{C}$ curve are reproduced in the $\delta^{13}$ Corg curve as previously noted by Pratt (1985). This indicates that the primary trend in the $\delta^{13} \mathrm{C}$ curve has been preserved.

Fig. 3. Correlation of the lithologic section at Pueblo described in this study with those presented in several previous studies: 1, this study; individual beds are numbered after Cobban and Scott (1972). 2, borehole PU-79-Pueblo, published by Pratt (1985), cored close to the Pueblo section outcrop. 3, Cobban (1985), with bed numbers after Cobban and Scott (1972), also utilized by Kennedy and Cobban (1991), by Gale et al. (1993), by Bengtson (1996), by Kennedy et al. (2000). a, position of the Cenomanian-Turonian boundary based on ammonite assemblage in Cobban and Scott (1972); also used by Pratt (1985: Fig. 2). b, position of the Cenomanian-Turonian boundary in Kennedy and Cobban (1991) defined at the base of the Watinoceras devonense ammonite zone; this level is also adopted by Bengtson (1996) and used in the present work.

Fig. 3. Corrélation de notre levé lithologique de la coupe de Pueblo, ainsi qu'il est décrit dans cette étude, avec les levés présentés par d'autres auteurs dans plusieurs études antérieures : 1, notre levé pour cette étude, les bancs ont été numérotés d'après Cobban et Scott (1972). 2, le forage PU-79-Pueblo, publié par Pratt (1985), prélevé près de l'affleurement de la coupe de Pueblo. 3, le levé de Cobban (1985), avec les numéros des bancs d'après Cobban et Scott (1972), utilisé aussi par Kennedy et Cobban (1991), par Gale et al. (1993), par Bengtson (1996), par Kennedy et al. (2000). a, position de la limite Cénomanien-Turonien basée sur les assemblages d'ammonites de Cobban et Scott (1972), utilisée aussi par Pratt (1985 : Fig. 2). b, position de la limite Cénomanien-Turonien d'après Kennedy et Cobban (1991) définie à la base de la zone d'ammonite Watinoceras devonense, ce niveau a été adopté par Bengtson (1996) et est aussi utilisé dans cette étude. 


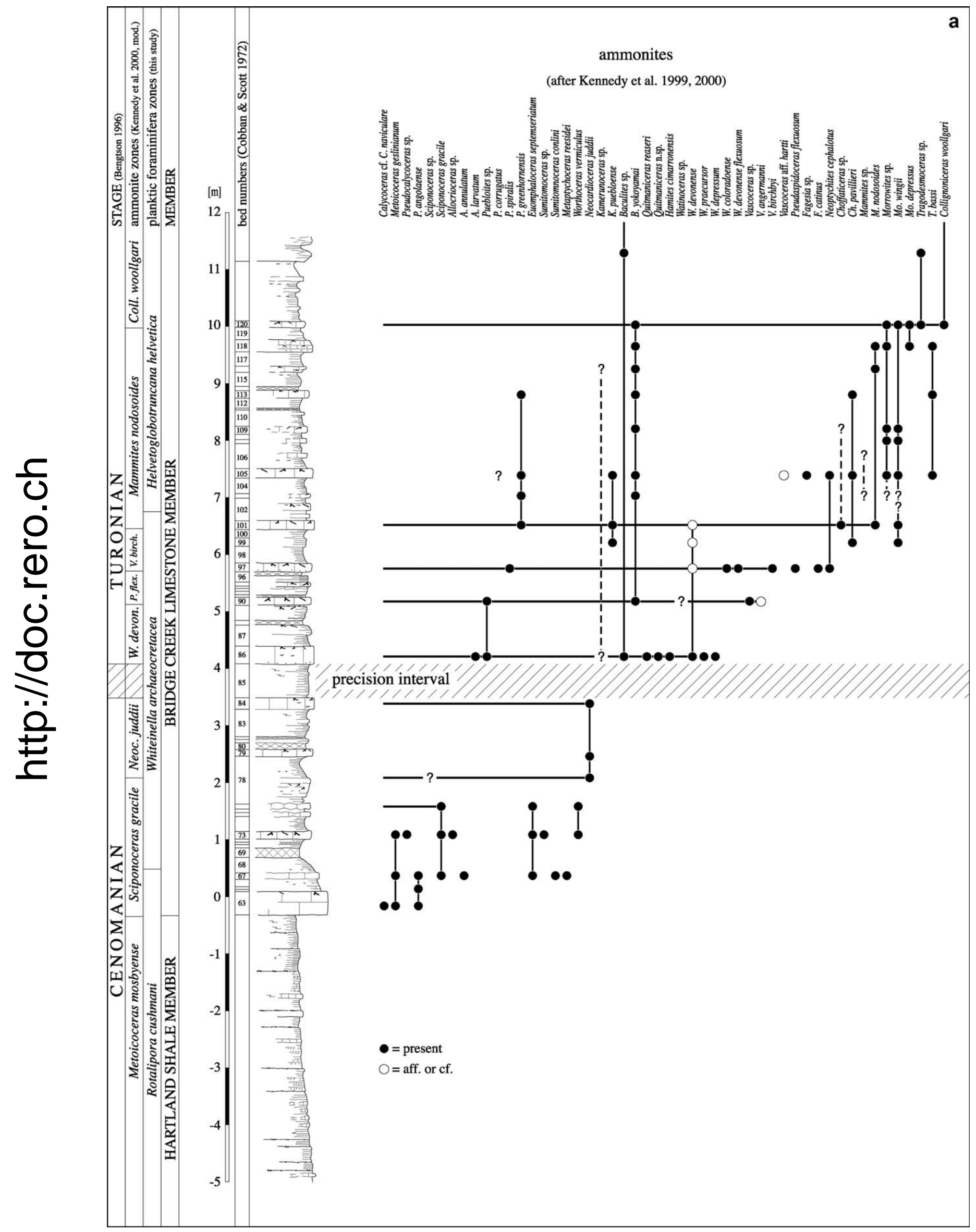




\section{The wadi Bahloul section}

The section is located $12 \mathrm{~km}$ to the south east of Maktar. The present study focuses on a $31 \mathrm{~m}$ succession that encompasses the Cenomanian-Turonian boundary interval. Preliminary studies of the lithology and biostratigraphy of this section have been recently conducted by several authors (Burollet and Robaszynski, 1991; Robaszynski et al., 1993a, 1993b; Ben Haj Ali et al., 1994; Maamouri et al., 1994; Caron et al., 1999). A first attempt of cyclostratigraphic analysis of the section (Caron et al., 1999) provided an estimate of 400,000 years for the duration of the Bahloul Formation. This result is re-examined here according to new ammonite findings. Samples from wadi Bahloul are identified by the letters "BLB" followed by their location in meters within the section.

\subsection{Lithology (Figs. 9 and 10)}

The Bahloul Formation overlaps the Fahdene Formation (Burollet et al., 1954) and is underlawn by the basal Annaba Member of the Kef Formation (Fournié, 1978). Accarie et al. (1996) described two sub-units within the Bahloul Formation: the inferior pre-Bahloul, and the superior Bahloul s.s. characterized by the typical laminated Bahloul facies. In this study, we follow these subdivisions:

\subsubsection{The pre-Bahloul (BLB $2.60 \mathrm{~m}$ to $6.00 \mathrm{~m}$ )}

The pre-Bahloul sub-unit starts at $2.40 \mathrm{~m}$ with a massive limestone bed that represents a sharp erosive contact overlaying the Fahdene Marls (a thick series consisting of gray to greenish marls interbedded with few calcisphere-rich limestones). The basal bed is $0.5 \mathrm{~m}$ thick and consists of normally graded and obliquely stratified microconglomeratic limestones, containing black phosphatic gravels and quartz grains. This bed is overlain by a $1.90-\mathrm{m}$-thick level of massive calcarenites, showing a faint grading of bioclastic components consisting of calcispheres, planktic and benthic foraminifera.

The top of the pre-Bahloul (Fig. 10(4)) is characterized by carbonate marls, showing a gradual decrease in quartz and bioclasts that are mainly composed of planktic foraminifera and calcispheres. Current driven sedimentary structures, evolving from low angular to parallel laminations, are visible in this bed. The carbonate marls are topped by a thin horizon of brownish marls. Above this horizon, the lithology changes abruptly into laminated limestone layers rich in organic matter that are characteristic of the Bahloul facies.

\subsubsection{The Bahloul sensu stricto (BLB $6 \mathrm{~m}$ to $B L B 33.30 \mathrm{~m}$ )}

This sub-unit consists of rhythmically bedded couplets of thinly bedded $(2-5 \mathrm{~cm})$ black limestones (Fig. 10(3)), containing sub-millimetric parallel laminations, and gray calcareous marls. These two lithologies represent the two end-members that alternate throughout this part of the section. These alternations are well expressed up to the BLB $27 \mathrm{~m}$ (Fig. 10(2)). Above this level, the contrast in carbonate content diminishes and the rhythmicity fades.

The highest concentrations of organic matter occur in the black laminated limestones. These laminations are composed of dark laminae, containing numerous pellets very rich in organic matter, and light colored laminae consisting of abundant shells of planktic foraminifera. The dark laminae are composed of oval pellets sometimes up to $1 \mathrm{~mm}$ long within a dark carbonate matrix containing dispersed radiolarians, buliminids, biand triserial and globulous trochospiral planktic foraminifera (microfacies on Fig. 10(3)). Light laminae mostly contain planktic foraminifera, i.e. numerous biserial heterohelicids associated with some large globulous trochospiral hedbergellids and whiteinellids. Benthic foraminifera are absent. These laminae can be followed laterally over several meters in the outcrop.

Limestones show a platy aspect with 10-50 laminae constituting one bed about $2-8 \mathrm{~cm}$ in thickness. The best examples for laminations are observed between BLB $21 \mathrm{~m}$ and $23 \mathrm{~m}$ (Fig. 10(3)). Small horizontal burrows are common. Occasionally Planolites-like burrows cross the lamination over several $\mathrm{cm}$. The transition towards the marls consists of a continuous decrease in the carbonate content. These transitional beds are fissile due to the presence of sub-millimetric laminations.

The second end member consists of bioturbated gray marls (microfacies on Fig. 10(2)), where laminations disappear. Iron oxide and/or pyrite concretions occur at several levels, and generally bound the limestone. In rare cases, they are observed within the more marly lithology. Between 33.10 and $33.40 \mathrm{~m}$ two burrowed limestone beds, bearing glauconite and phos-

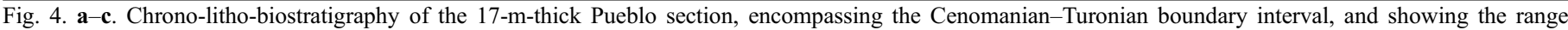

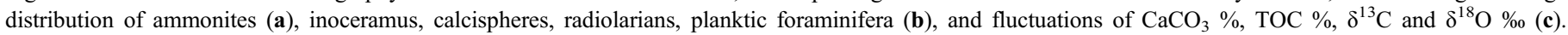

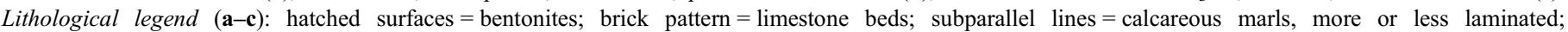

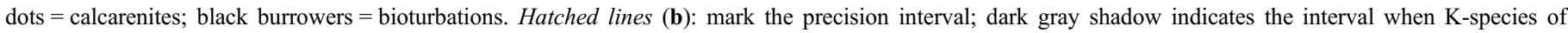

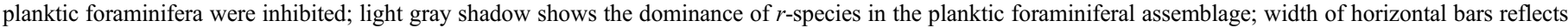

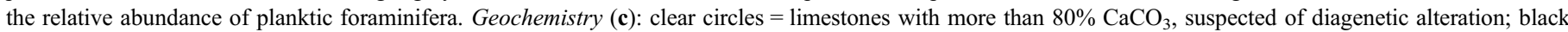
circles = marly limestones; I, II, III = main peaks in the $\delta^{13} \mathrm{C}$ profile.

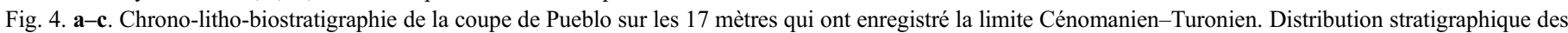

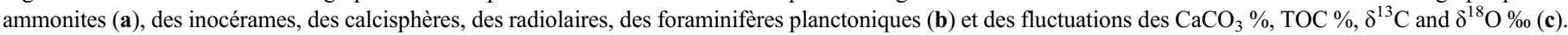

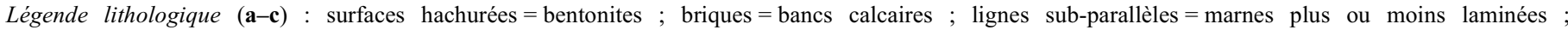

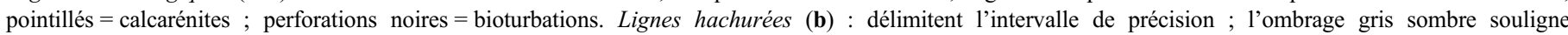

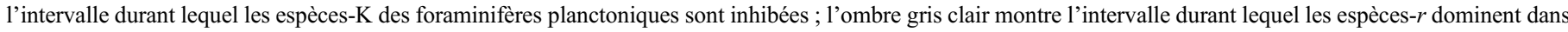

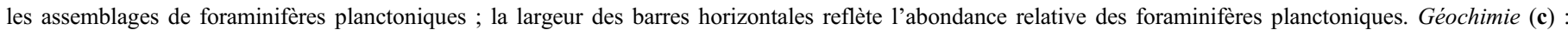

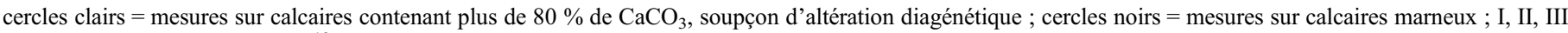
$=$ pics principaux sur le profil $\delta^{13} \mathrm{C}$. 


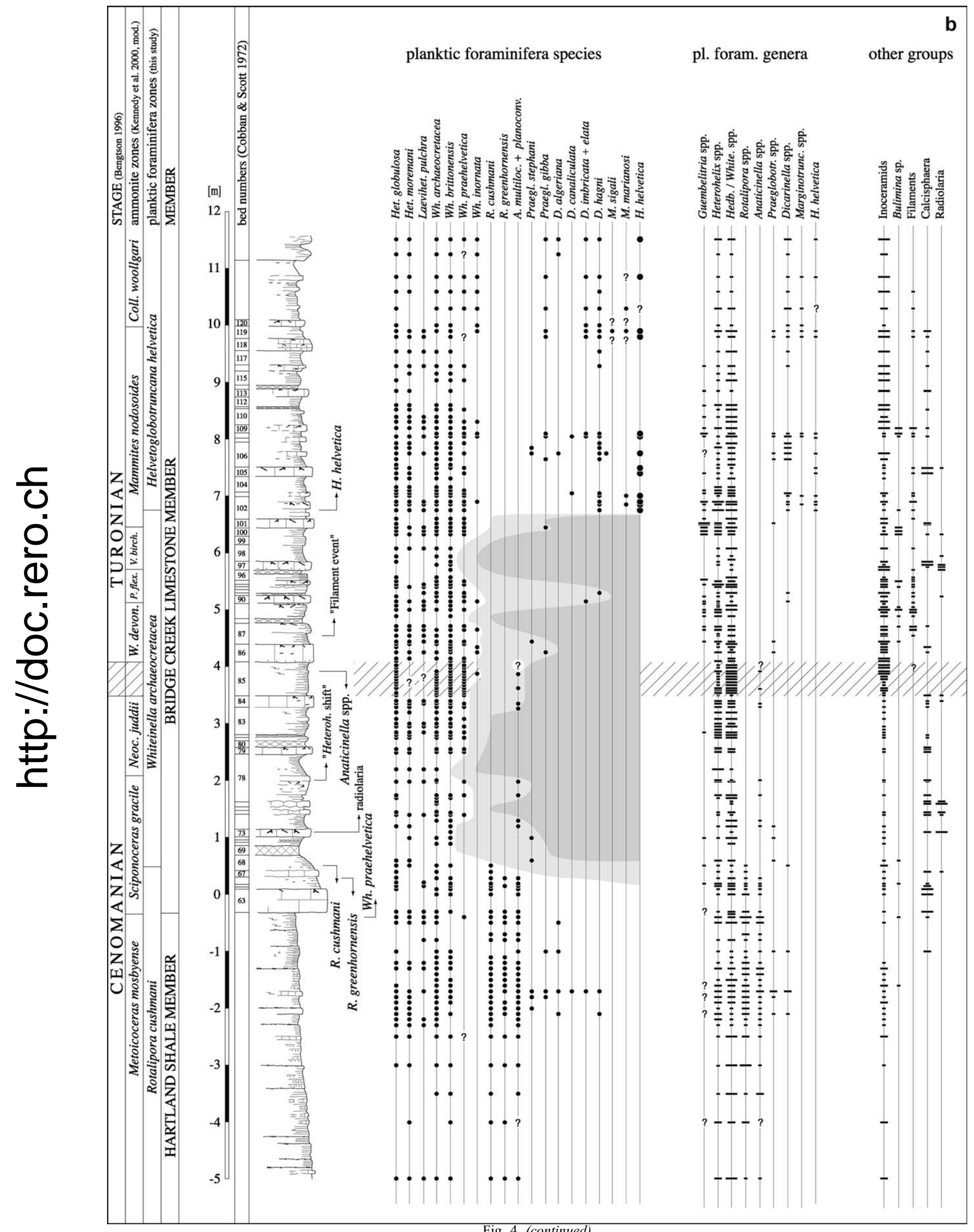




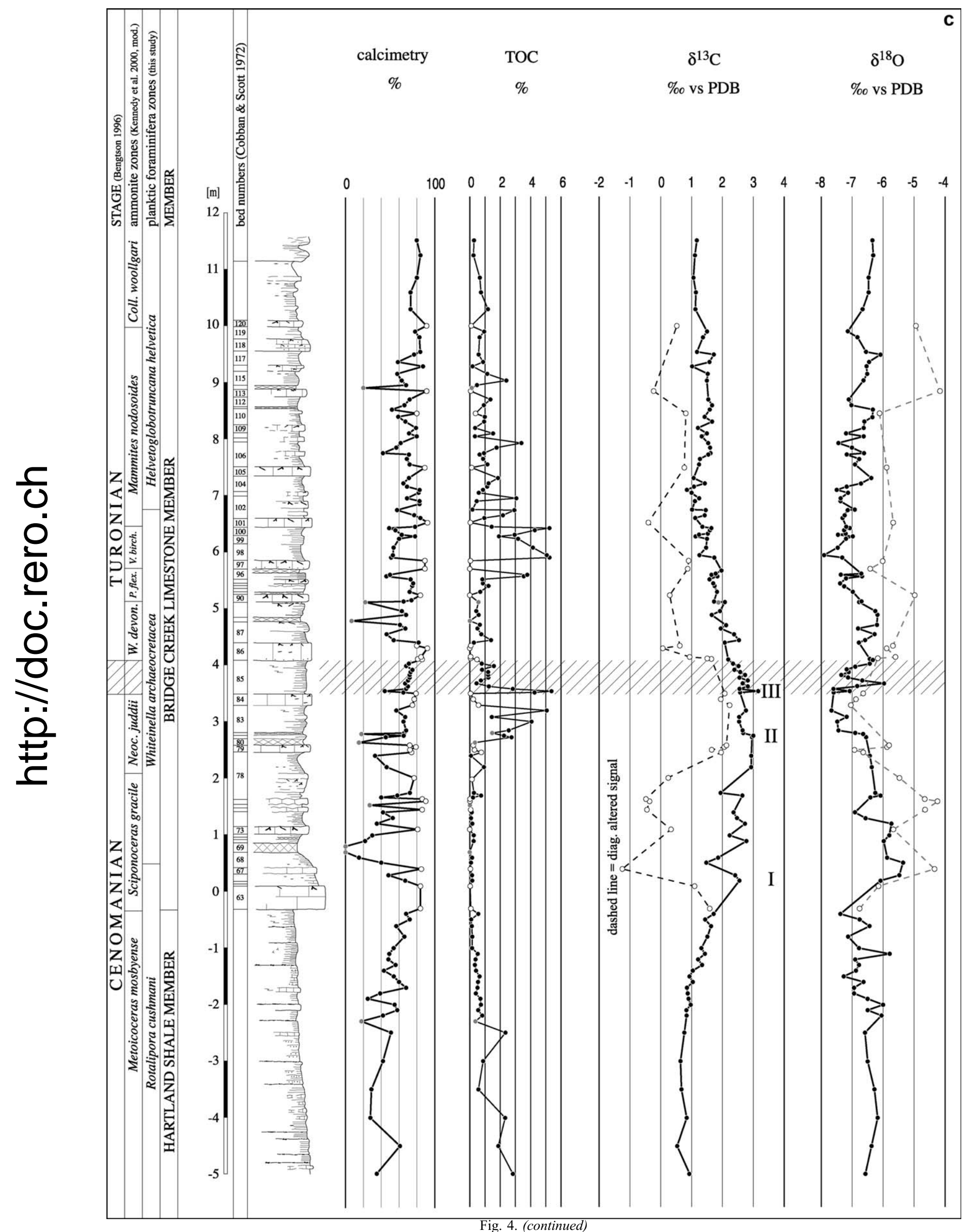



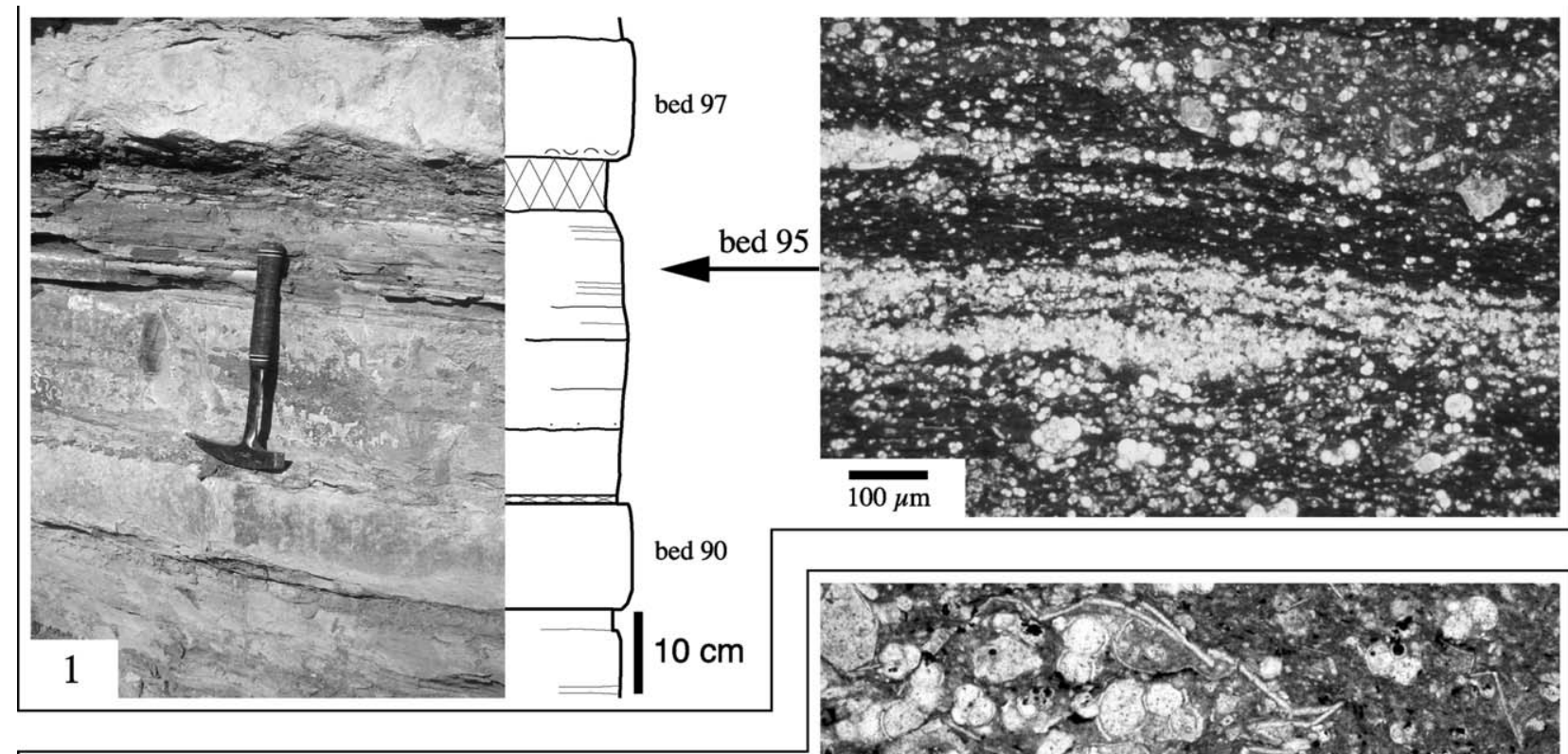

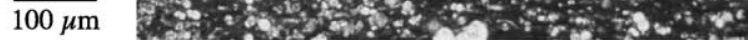

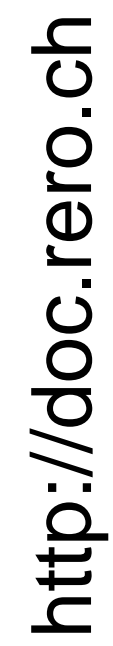

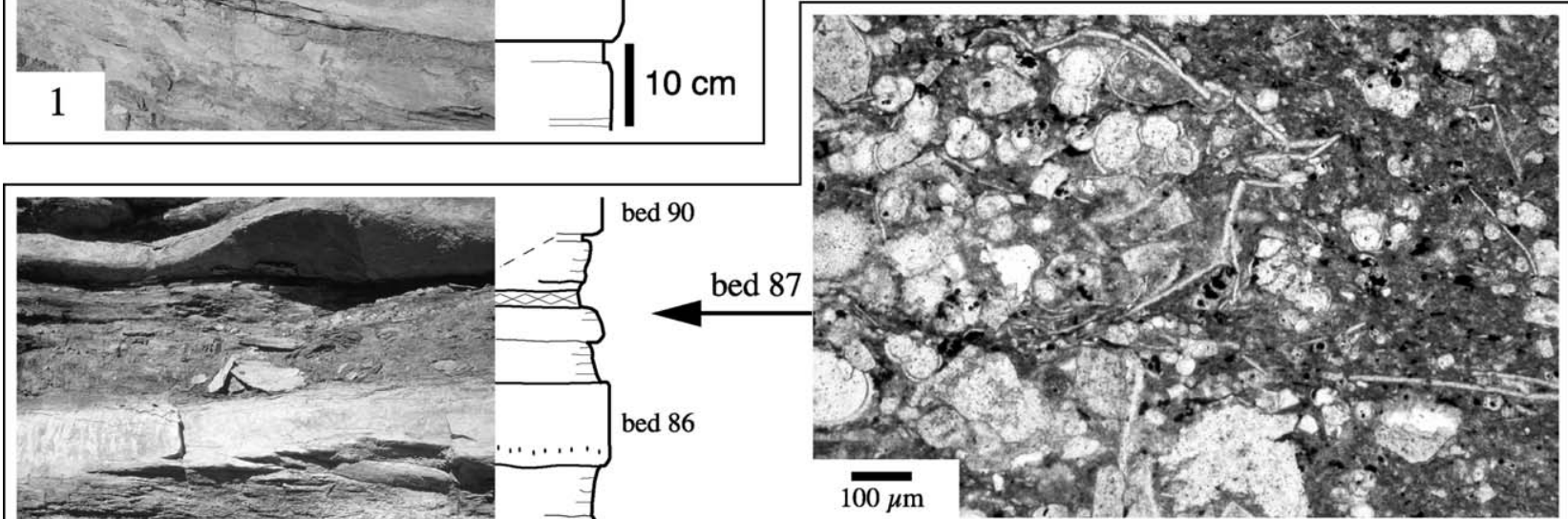

$2 \quad \mathrm{~cm}=2-\infty \mathrm{cm}$
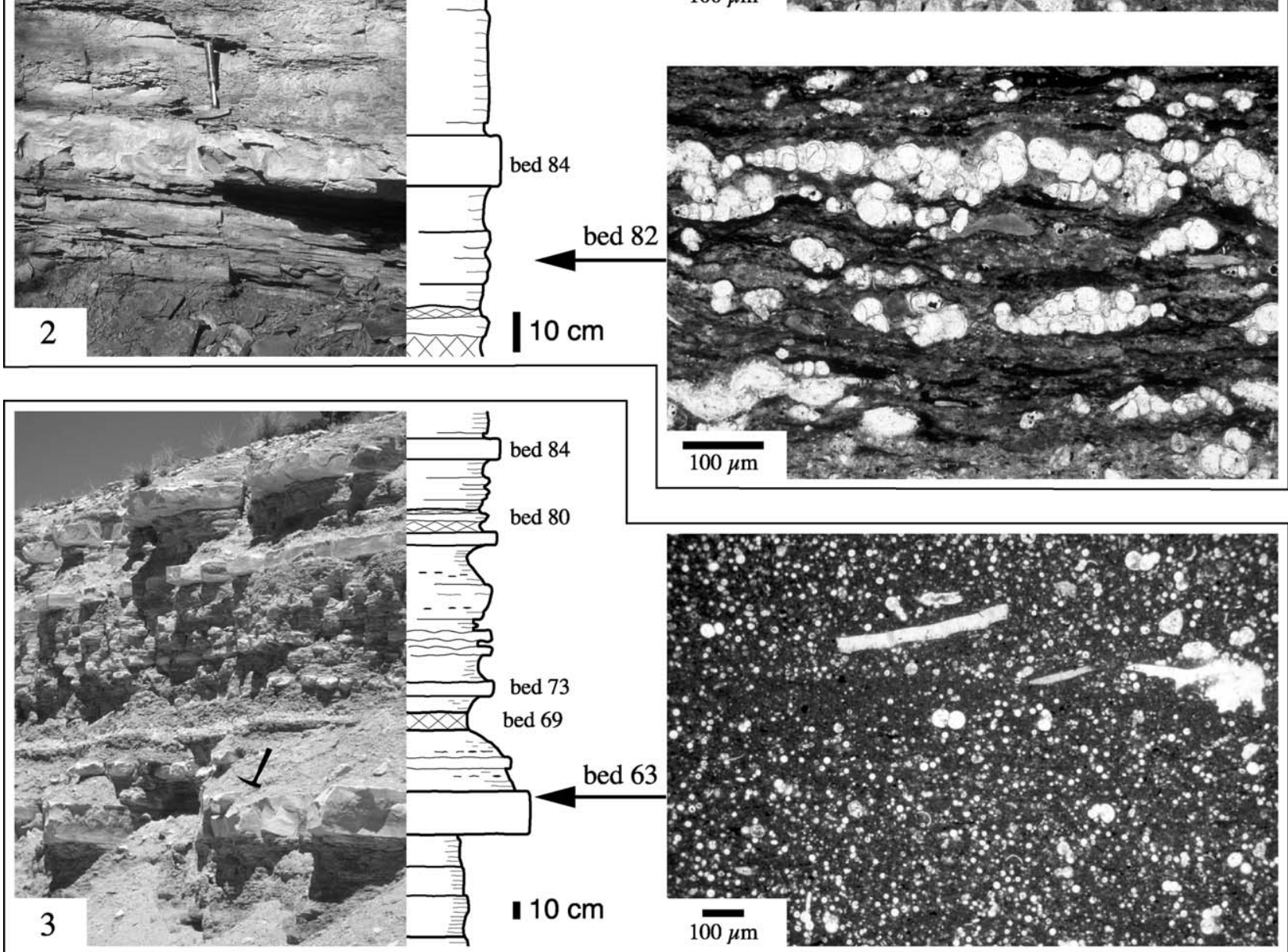


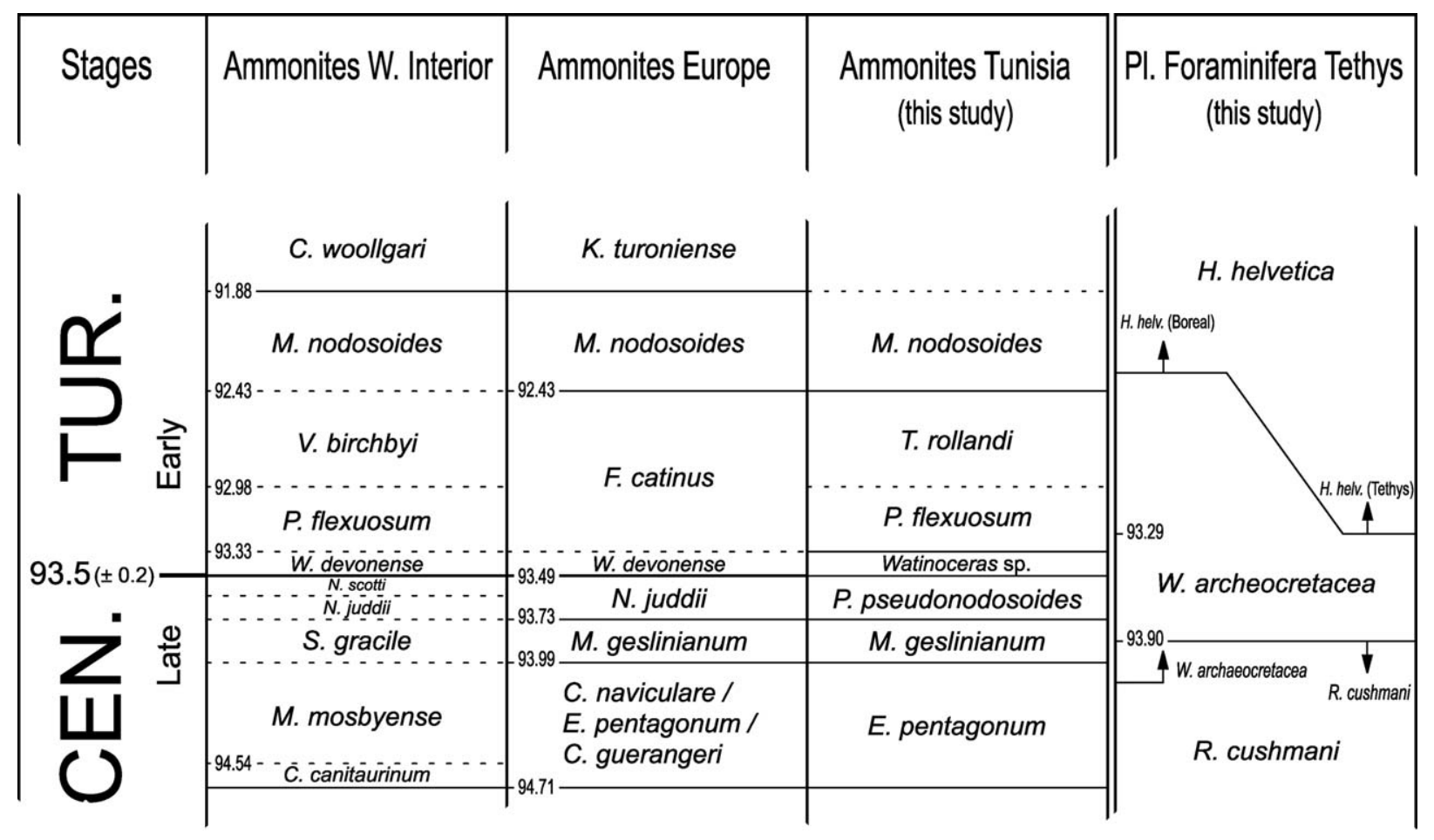

Fig. 6. Bio- and chrono-stratigraphy of the Cenomanian-Turonian boundary interval (data adapted from the chart of Hardenbol et al., 1998) in the three different realms, i.e. for the Western Interior Basin, Europe and (modified in the present study) Tunisia.

Fig. 6. Bio- et chrono-stratigraphie de l'intervalle recouvrant la limite Cénomanien-Turonien (données adaptées de la charte de Hardenbol et al., 1998) dans les trois domaines différents, c'est à dire pour le Bassin du Western Interior, pour l'Europe et (modifié selon la présente étude) pour la Tunisie.

phate grains, occur (microfacies on Fig. 10(1)). Here the top of the Bahloul Formation is marked by a drastic change in lithology as it is overlain by the thick series of blue-gray calcareous marls of the Annaba Member.

\subsection{Biostratigraphy}

\subsubsection{Ammonites (Fig. 9a)}

The stratigraphic distribution of ammonites at the wadi Bahloul section has been intensively studied during the last two decades (Robaszynski et al., 1993a, 1993b; Ben Haj Ali et al., 1994; Caron et al., 1999; Amédro et al., in press). New observations presented here provide additional information and allow a more precise identification of species ranges. A number of ammonite zones have been identified, and directly or indirectly correlated. These are:

- Metoicoceras geslinianum Zone (correlative) (from BLB $3 \mathrm{~m}$ to BLB $10 \mathrm{~m}$ );

This zone occurs at the lower part of the studied interval and is identified by the presence of Pseudocalycoceras angolaense at BLB $5.20 \mathrm{~m}$. The range of this species is usually confined within the Metoicoceras geslinianum Zone, and does not extend into younger sediments (Cobban, 1988). Taking into account the ammonite findings in the Kalaat Senan area (Jebel Azreg, sections AZ-ZR), the base of the

Fig. 5. Outcrop and microfacies at Pueblo section (PB). 1. Field view of beds 90 to 97, encompassing the Pseudaspidoceras flexuosum zone. Detailed microfacies of bed 95, showing infra-millimetric laminations, similar to those of the "Bahloul facies"; white laminae with Heterohelix and Whiteinella, dark laminae with organic matter-rich pellets; bed 95 truncated atop by bioturbation. 2. Field view from bed 80 (bentonite B) up to bed 90 (above bentonite C); The Cenomanian-Turonian precision interval is delimited between the top of bed 84 and the base of bed 86 . Detailed microfacies of bed 87 showing the first "filaments" in a packstone of Inoceramus prisms and planktic foraminifera. Detailed microfacies of bed 82 showing white laminae (abundant planktic foraminifera distributed in laminae, characteristic of the Heterohelix shift) and dark laminae (organic matter-rich pellets, flattened by compaction). 3. Field view of beds 63 to 84 , last Cenomanian (ammonites) beds in this section. Detailed microfacies of bed 63: wackestone/packstone with abundant calcispheres, Inoceramus prisms and diversified planktic foraminifera (Heterohelix, Hedbergella/Whiteinella, Praeglobotruncana, Rotalipora, Anaticinella, not all visible in this thin section).

Fig. 5. Affleurement et microfaciès de la coupe de Pueblo (PB). 1. Vue de terrain des bancs 90 à 97 , recouvrant la zone à Pseudaspidoceras flexuosum. Microfaciès détaillé du banc 95, montrant les laminations infra-millimétriques, semblables à celles du " faciès Bahloul »; lamines claires à Heterohelix et Whiteinella, lamines sombres à pelotes fécales riches en matière organique ; le sommet du banc 95 est tronqué par des bioturbations. 2. Vue de terrain à partir du banc 80 (bentonite B) jusqu'au banc 90 (au-dessus de la bentonite C) ; l'intervalle de précision pour la limite Cénomanien-Turonien est compris entre le sommet du banc 84 et la base du banc 86 . Microfaciès détaillé du banc 87 montrant les premiers « filaments » dans un packstone de prismes d'Inoceramus et de foraminifères planctoniques. Microfaciès détaillé du banc 82 montrant les lamines claires (foraminifères planctoniques abondants distribués en lamines, caractéristiques du shift des Heterohelix) et les lamines sombres (pelotes fécales riches en matière organique, aplaties par la compaction). 3. Vue de terrain des bancs 63 à 84, derniers bancs du Cénomanien supérieur (ammonites) sur cette coupe. Microfaciès détaillé du banc 63 : wackestone/packstone à calcisphères abondantes, prismes d'Inoceramus et foraminifères planctoniques diversifiés (Heterohelix, Hedbergella/Whiteinella, Praeglobotruncana, Rotalipora, Anaticinella, pas tous visibles sur cette photo). 


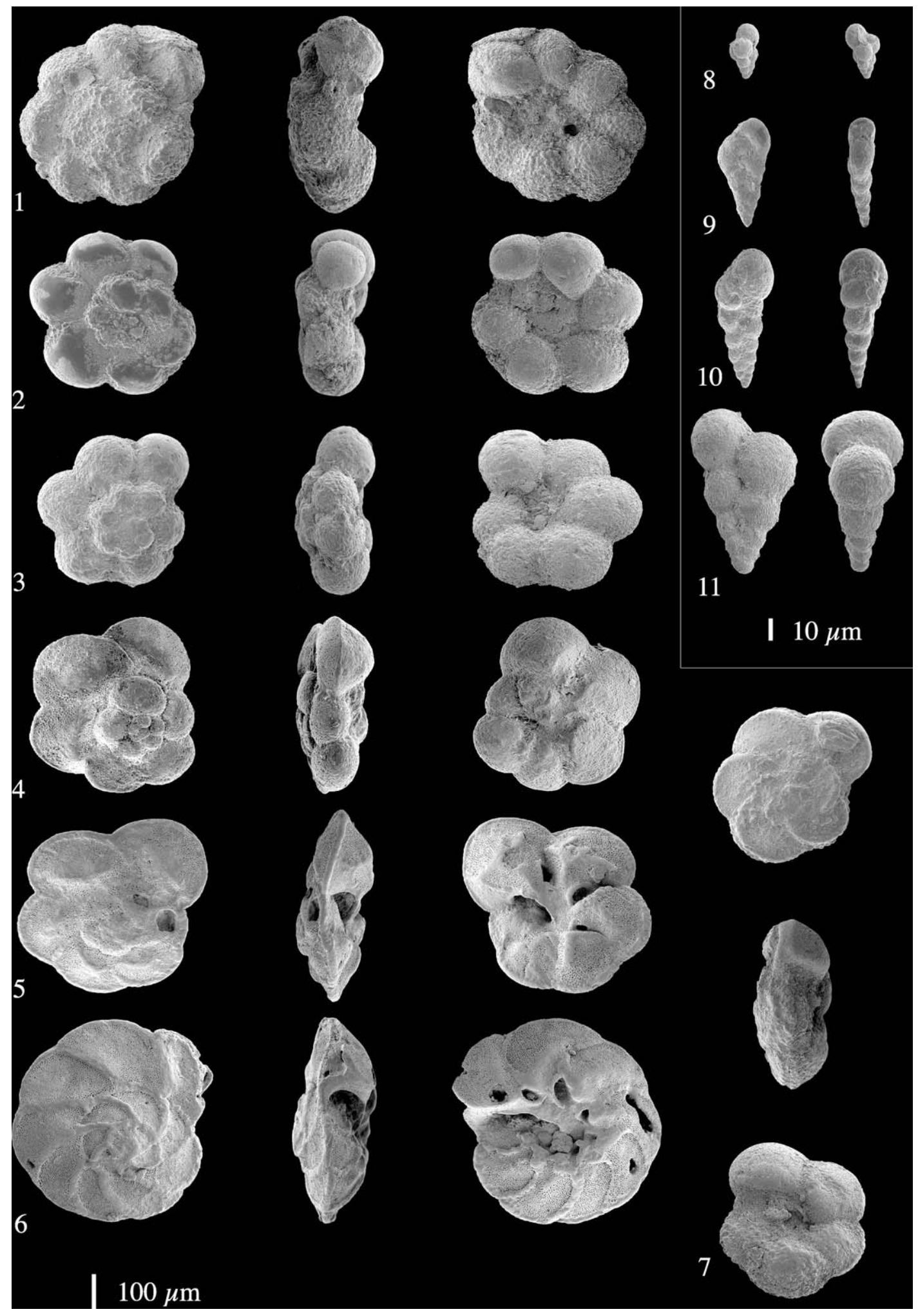

Fig. 7. SEM-microphotos of planktic foraminifera. 1. Helvetoglobotruncana helvetica (BLB $33.40 \mathrm{~m})$. 2. Whiteinella praehelvetica (BLB $33.40 \mathrm{~m})$. 3. Whiteinella archaeocretacea $(\mathrm{PB}+7.75 \mathrm{~m})$. 4. Anaticinella planoconvexa $(\mathrm{PB}-3.00 \mathrm{~m})$. 5. Rotalipora cushmani $(\mathrm{BLB} 2.30 \mathrm{~m})$. 6. Rotalipora greenhornensis $(\mathrm{BLB} 2.30 \mathrm{~m}) .7$. Dicarinella hagni $(\mathrm{PB}+7.65 \mathrm{~m})$. 8. Guembelitria cretacea $(\mathrm{PB}+1.00 \mathrm{~m})$. 9. Laeviheterohelix pulchra $(\mathrm{BLB} 33.40 \mathrm{~m})$. 10. Heterohelix moremani $(\mathrm{BLB} 33.40 \mathrm{~m})$. 11. Heterohelix globulosa (BLB $33.40 \mathrm{~m}$ ).

Fig. 7. Microphotos au MEB des foraminifères planctoniques. 1. Helvetoglobotruncana helvetica (BLB 33,40 m). 2. Whiteinella praehelvetica (BLB $33,40 \mathrm{~m})$. 3. Whiteinella archaeocretacea $(\mathrm{PB}+7,75 \mathrm{~m})$. 4. Anaticinella planoconvexa $(\mathrm{PB}-3,00 \mathrm{~m})$. 5. Rotalipora cushmani $(\mathrm{BLB} 2,30 \mathrm{~m})$. 6. Rotalipora greenhornensis $(\mathrm{BLB}$ 2,30 m). 7. Dicarinella hagni $(\mathrm{PB}+7,65 \mathrm{~m})$. 8. Guembelitria cretacea $(\mathrm{PB}+1,00 \mathrm{~m})$. 9. Laeviheterohelix pulchra $(\mathrm{BLB} 33,40 \mathrm{~m}) .10$. Heterohelix moremani $(\mathrm{BLB}$ $33,40 \mathrm{~m})$. 11. Heterohelix globulosa (BLB $33,40 \mathrm{~m}$ ). 
M. geslinianum Zone should be placed at the lower limit of the pre-Bahloul unit (Amédro et al.,, in press).

- Pseudaspidoceras pseudonodosoides Zone (from BLB $10 \mathrm{~m}$ to BLB $27.00 \mathrm{~m}$ );

The first specimen of Pseudaspidoceras pseudonodosoides was found at BLB $10 \mathrm{~m}$ and defines the base of the zone. The last specimen was collected at BLB $27.0 \mathrm{~m}$, which corresponds to the uppermost level containing Cenomanian ammonites. The Pseudaspidoceras pseudonodosoides Zone is equivalent to the Neocardioceras juddii Zone from the boreal realm or the Western Interior Seaway.

- Watinoceras sp. Zone (from BLB $27.60 \mathrm{~m}$ to BLB $33.00 \mathrm{~m}$ );

The first Turonian ammonite, Watinoceras sp. (3 specimens), was observed at BLB $27.60 \mathrm{~m}$, defining the base of this zone. The $\mathrm{C} / \mathrm{T}$ boundary lays somewhere between BLB $27 \mathrm{~m}$ and $27.60 \mathrm{~m}$. In addition, at BLB $32.5 \mathrm{~m}$ was observed the first occurrence of Fagesia sp. This morphotype occurs throughout the studied interval and above (at BLB $54 \mathrm{~m}$ and $82 \mathrm{~m}$ ).

- Pseudaspidoceras flexuosum Zone (correlative) (towards BLB $33.40 \mathrm{~m}-33.60 \mathrm{~m}$ );

The presence of the Pseudaspidoceras flexuosum Zone is inferred by correlation with the sections at wadi Smara (Robaszynski et al., 1990) and at koudiat Azreg (Accarie et al., 2000). No specimens of $P$. flexuosum have been yet found in the wadi Bahloul section.

- Thomasites rollandi Zone (correlative) (from BLB $33.60 \mathrm{~m}$ to the top of the studied section);

The T. rollandi Zone of Chancellor et al. (1994) corresponds to the Choffaticeras interval of Robaszynski et al. (1990). At BLB $33.60 \mathrm{~m}$, Thomasites sp. was collected. The range of Thomasites sp. is known to extend from the top of the Cenomanian to the Mammites nodosoides Zone (top of the Early Turonian). Following Robaszynski et al. (1990) this specimen dates the lower Turonian.

- Mammites nodosoides Zone (base at BLB $55.0 \mathrm{~m}$ ).

The base of the Mammites nodosoides Zone is placed at BLB $55.0 \mathrm{~m}$ based on the first occurrence of this taxon. Although this datum is more than $10 \mathrm{~m}$ above the studied interval, it is important for the correlation of this section with the Pueblo section. Additional ammonites were found higher in the section, such as Kamerunoceras turoniense at BLB 68,88 and $94.5 \mathrm{~m}$.

\subsubsection{Planktic foraminifera (Figs. 7,8 and $9 a$}

The following three zones as defined by Robaszynski and Caron $(1979,1995)$ have been identified at the wadi Bahloul section:

- Upper part of the Rotalipora cushmani TRZ (from the base of the studied section up to BLB $5.75 \mathrm{~m}$ ).

$R$. cushmani is abundant within the Fahdene marls but becomes very rare within the pre-Bahloul facies. The LO of $R$. greenhornensis (BLB $5.25 \mathrm{~m}$ ) precedes the LO of R. cushmani (BLB $5.75 \mathrm{~m}$ ), which falls in the interval be- tween the Metoicoceras geslinianum and the Pseudaspidoceras pseudonodosoides ammonite Zones. This is consistent with the range of this taxon at the sections of wadi Mellegue (Nederbragt and Fiorentino, 1999), wadi Smara (Robaszynski et al., 1990), and koudiat Azreg (Amédro et al., in press) in Central Tunisia. This zone is characterized by high species diversity, which includes the presence of Whiteinella archaeocretacea, $W$. praehelvetica (FO at BLB $5.50 \mathrm{~m})$, Praeglobotruncana gibba, Dicarinella algeriana, some specimens of Anaticinella multiloculata and A. planoconvexa, and Rotalipora sp. A rapid drop in species diversity characterizes the top of the $R$. cushmani Zone.

- Whiteinella archaeocretacea PRZ (from BLB $5.75 \mathrm{~m}$ to BLB $33.25 \mathrm{~m}$ ).

The LO of R. cushmani is recorded at BLB $5.75 \mathrm{~m}$ and the FO of Helvetoglobotruncana helvetica at BLB $33.25 \mathrm{~m}$. This zone corresponds to the interval spanning the top of the M. geslinianum ammonite Zone to the base of the inferred P. flexuosum ammonite Zone. Planktic foraminiferal species diversity is reduced in this PRZ, which is dominated by the proliferation of heterohelicids, hedbergellids and whiteinellids. Heterohelicids increase in abundance from BLB $6.20 \mathrm{~m}$. This "Heterohelix shift" has already been observed in Central Tunisia (Robaszynski et al., 1993a; Nederbragt and Fiorentino, 1999). The LO of Anaticinella planoconvexa is identified at BLB $27.20 \mathrm{~m}$ within the $\mathrm{C} / \mathrm{T}$ precision interval.

- Helvetoglobotruncana helvetica TRZ (from BLB 33.25 m upwards).

The FO of $H$. helvetica is observed at the base of the bioturbated beds, which correspond to the base of the P. flexuosum ammonite Zone inferred by regional correlation. Diversity of keeled planktic foraminiferal species shows a rapid increase at this level.

\subsection{Geochemistry (Fig. 9b)}

\subsubsection{Total organic carbon}

TOC values fluctuate from 0.5 to about $8 \%$ with high amplitude variations in some intervals. These values are consistent with the published data from the same geographical area (Herbin et al., 1986). The increase of TOC values begin within the pre-Bahloul facies. Maximum values are observed in the lower part of the Bahloul s.s between BLB $11 \mathrm{~m}$ and BLB $16 \mathrm{~m}$. Values then decline to a minimum of $\sim 0.5 \%$ at BLB $23 \mathrm{~m}$. A successive increase to $3-4 \%$ persists up to BLB $33.25 \mathrm{~m}$. The condensed surface at this level is associated with a sudden decrease of $3 \%$ in TOC values. Above that, within the Kef Formation the TOC content is low, close to zero.

At the scale of the limestone/marl alternation, the relation between TOC versus lithology is obvious (Caron et al., 1999). High TOC values $(>3 \%)$ are recorded in calcareous facies in intervals where bioturbated marly levels have minimal values $(1.5-2 \%)$. TOC fluctuations are positively correlated with $\mathrm{CaCO}_{3}$ content. 

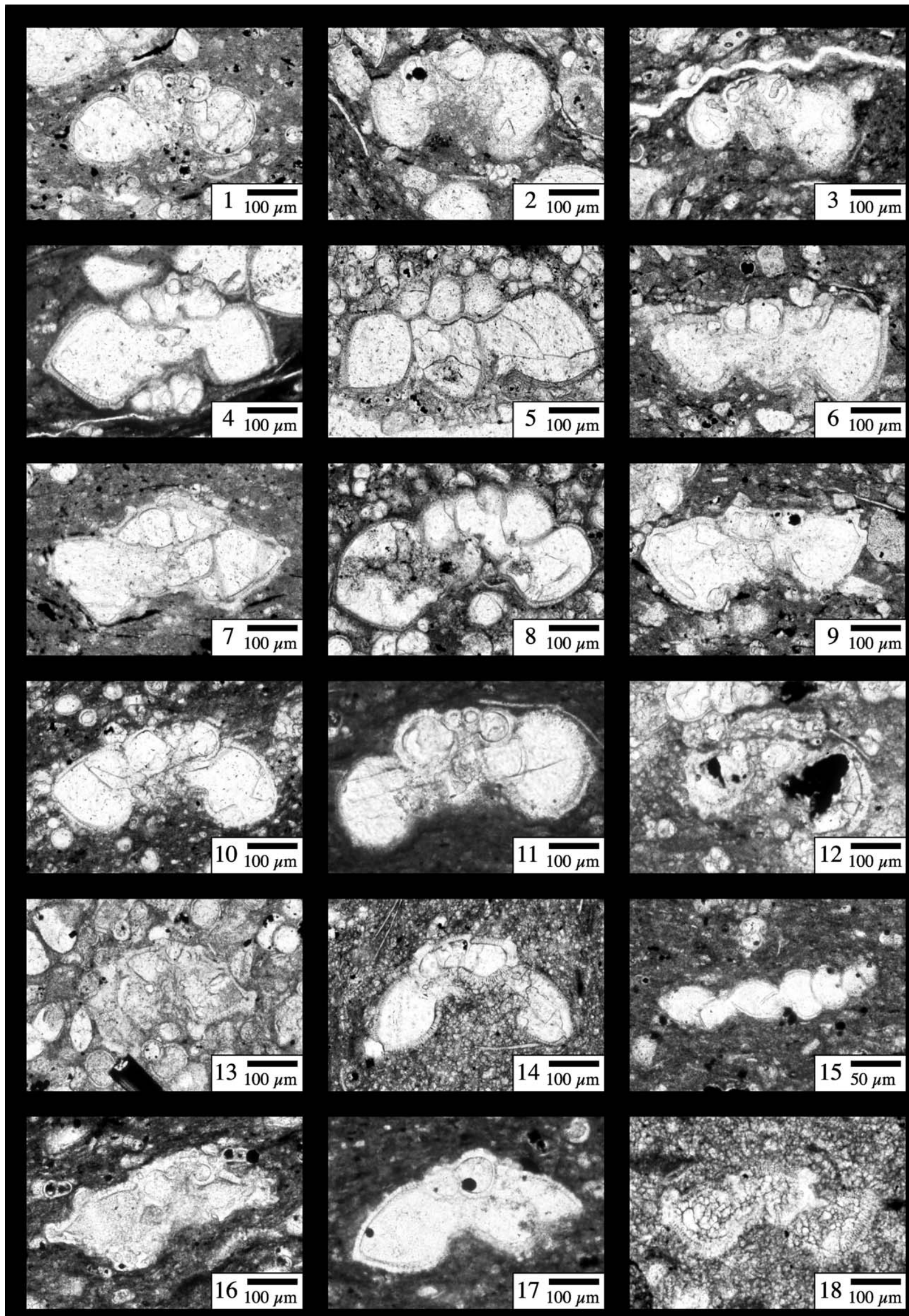


\subsubsection{Stable carbon isotopes}

Recent studies in Central Tunisia have documented a positive $\delta^{13} \mathrm{C}$ excursion of about 2\%o within the Late Cenomanian to Early Turonian of the Bahloul Formation of (Accarie et al., 1996; Nederbragt and Fiorentino, 1999; Accarie et al., 2000). In the wadi Bahloul section, our high resolution data show the details of this isotopic excursion with several marked events, noted as peaks I, II and III. In the pre-Bahloul facies, between BLB $5 \mathrm{~m}$ and BLB $6 \mathrm{~m}, \delta^{13} \mathrm{C}$ values record an abrupt increase from 1.8 to $3 \%$, identified as peak I. Values remain around $3.2 \%$ for the next 12 meters, and the end of this plateau is peak II. These values are followed by a rapid and important inversion to about $1.5 \%$. An additional maximum of about $3.5 \%$ is observed at BLB $20.50 \mathrm{~m}$. Values remain high up to BLB $24.50 \mathrm{~m}$ (peak III), before decreasing gradually to about $2 \%$ from BLB $30 \mathrm{~m}$ up to the top of the section.

At top of the Fahdène Formation as well as at base of the Kef Formation, $\delta^{13} \mathrm{C}$ values seem to be strongly affected by diagenetic alteration. The isotopic signals may be altered at top of the Fahdène Fm which is overlain by thick micro-conglomeratic limestone in a sharp erosive contact (cf. Section 6.1.1. the pre-Bahloul facies). At top of the Bahloul Fm, two bored surfaces (BLB 33.10 and $33.40 \mathrm{~m}$ ) may have stopped downwards the diagenetic alteration as evidenced by the covariance of $\delta^{13} \mathrm{C}$ and $\delta^{18} \mathrm{O}$ values above BLB $33.40 \mathrm{~m}$ (Fig. 9b).

\section{Comparisons and discussion}

\subsection{Lithology (Figs. 4a and 9a)}

The wadi Bahloul section consists of a thick series (more than $25 \mathrm{~m}$ ) of Bahloul facies s.s bounded by unconformities and characterized by evident lithological changes. In contrast, the Pueblo section is strongly condensed, especially the Bridge Creek Formation $(12 \mathrm{~m})$. Yet interruptions in the continuity of depositional sequences are not apparent.

At the lower part of both sections, sediments show evidence of hydrodynamic processes and of detrital material transported from shallower water environments (Elder and Kirkland, 1985; Caron et al., 1999).

The Bridge Creek Member and the Bahloul Formation s.s are composed of rhythmic alternations of limestone/marlstone couplets that were interpreted as driven by climatic changes (Pratt, 1985; Sageman et al., 1997; Elder, 1985; Caron et al., 1999). In the Pueblo section, the marlstone beds are laminated and rich in organic carbon. On the contrary in the wadi Bahloul section richness in organic carbon and laminations characterize the limestone beds. Such a positive correlation between TOC and $\mathrm{CaCO}_{3}$, at Bahloul, is unusual and suggests a link between carbonate and organic productivity at the area (Ricken, 1993). Nevertheless, although depositional and environmental settings were different, the sediments from the two sections record similar events across the $\mathrm{C} / \mathrm{T}$ boundary.

\subsection{Ammonites (Figs. 6 and 11)}

The ammonite associations recorded at Pueblo and wadi Bahloul sections are on the whole comparable. One remark about Fig. 6 is necessary: it concerns the correlation between the Tunisian Pseudaspidoceras pseudonodosoides Zone with the north-American Neocardioceras juddii Zone. P. pseudonodosoides (Choffat) is a species known in Upper Cenomanian from Portugal, Tunisia, Israel and North America (New Mexico, Arizona, Trans-Pecos Texas). But it should be noted that the best records of $P$. pseudonodosoides are in New Mexico, where the species is restricted to the $N$. juddii Zone (Cobban et al., 1989). Therefore, the Tunisian $P$. pseudonodosoides ammonite Zone can be correlated with the boreal $N$. juddii Zone.

\subsection{Microfaunal events (Figs. 4b,9a and 11)}

\subsubsection{LO Rotalipora}

The last occurrence of specimens belonging to the genus Rotalipora (R. cushmani) occurs at the Pueblo section (PB $0.50 \mathrm{~m}=$ bed 68 ) in the $S$. gracile ammonite Zone, and at wadi Bahloul (BLB $6.00 \mathrm{~m}$ ) at the top of $M$. geslinianum Zone. At both sites, the LO of $R$. greenhornensis shortly precedes the LO of R. cushmani (details on Figs. 4b and 9a). Based on the inferred ammonite correlation and the time control provided by ammonite zones (Fig. 10), the LO of the genus Rotalipora should be considered to be synchronous at the two localities (Fig. 11). Double-keeled species (Praeglobotruncana, Dicarinella) occur in the upper Cenomanian. They disappear briefly before the LO of the single-keeled Rotalipora, and reappear in large numbers at the end of the turnover (see discussion in "turnover", this paper). These keeled forms are complex morphotypes and their disappearance marks the onset of a major biological turnover. It should be noted that they disappear above the $\delta^{13} \mathrm{C}$ peak I. This peak is a result of enhanced burial

Fig. 8. Characteristic thin sections of planktic foraminifera. At Pueblo section. 1. Whiteinella archaeocretacea (PB $+6.75 \mathrm{~m}) .2$. Whiteinella praehelvetica (PB $+3.95 \mathrm{~m})$. 3. Helvetoglobotruncana helvetica $(\mathrm{PB}+9.80 \mathrm{~m})$. 4. Rotalipora cushmani $(\mathrm{PB}-2.10 \mathrm{~m})$. 5. Anaticinella planoconvexa $(\mathrm{PB}-3.50 \mathrm{~m}) .6$. Dicarinella elata $(\mathrm{PB}+6.90 \mathrm{~m})$. 7. Rotalipora greenhornensis $(\mathrm{PB}-2.10 \mathrm{~m})$. 8. Anaticinella multiloculata $(\mathrm{PB}-3.50 \mathrm{~m})$. 9. Dicarinella hagni $(\mathrm{PB}+6.90 \mathrm{~m})$. At wadi Bahloul section. 10. Whiteinella archaeocretacea. (BLB $22.80 \mathrm{~m}$ ). 11. Whiteinella praehelvetica (BLB $29.80 \mathrm{~m})$. 12. Helvetoglobotruncana helvetica (BLB $33.25 \mathrm{~m}) .13$. Rotalipora greenhornensis (BLB $5.10 \mathrm{~m}$ ). 14. Praeglobotruncana gibba (BLB $37.00 \mathrm{~m}$ ). 15. Lunatriella sp. (BLB $27.20 \mathrm{~m})$. 16. Rotalipora cushmani (BLB 5.75 m). 17. Anaticinella planoconvexa (BLB $27.20 \mathrm{~m})$. 18. Dicarinella hagni (BLB $43.50 \mathrm{~m}$ ).

Fig. 8. Foraminifères planctoniques caractéristiques en plaques minces. A la coupe de Pueblo. 1. Whiteinella archaeocretacea (PB $+6,75 \mathrm{~m})$. 2. Whiteinella praehelvetica $(\mathrm{PB}+3,95 \mathrm{~m})$. 3. Helvetoglobotruncana helvetica $(\mathrm{PB}+9,80 \mathrm{~m})$. 4. Rotalipora cushmani $(\mathrm{PB}-2,10 \mathrm{~m}) .5$. Anaticinella planoconvexa $(\mathrm{PB}-3,50 \mathrm{~m}) .6$. Dicarinella elata $(\mathrm{PB}+6,90 \mathrm{~m})$. 7. Rotalipora greenhornensis $(\mathrm{PB}-2,10 \mathrm{~m})$. 8. Anaticinella multiloculata $(\mathrm{PB}-3,50 \mathrm{~m})$. 9. Dicarinella hagni $(\mathrm{PB}+6,90 \mathrm{~m})$. A la coupe de l'oued Bahloul. 10. Whiteinella archaeocretacea. (BLB 22,80 m). 11. Whiteinella praehelvetica (BLB 29,80 m). 12. Helvetoglobotruncana helvetica (BLB $33,25 \mathrm{~m}$ ). 13. Rotalipora greenhornensis (BLB 5,10 m). 14. Praeglobotruncana gibba (BLB 37,00 m). 15. Lunatriella sp. (BLB 27,20 m). 16. Rotalipora cushmani (BLB 5,75 m). 17. Anaticinella planoconvexa (BLB 27,20 m). 18 Dicarinella hagni (BLB 43,50 m) 


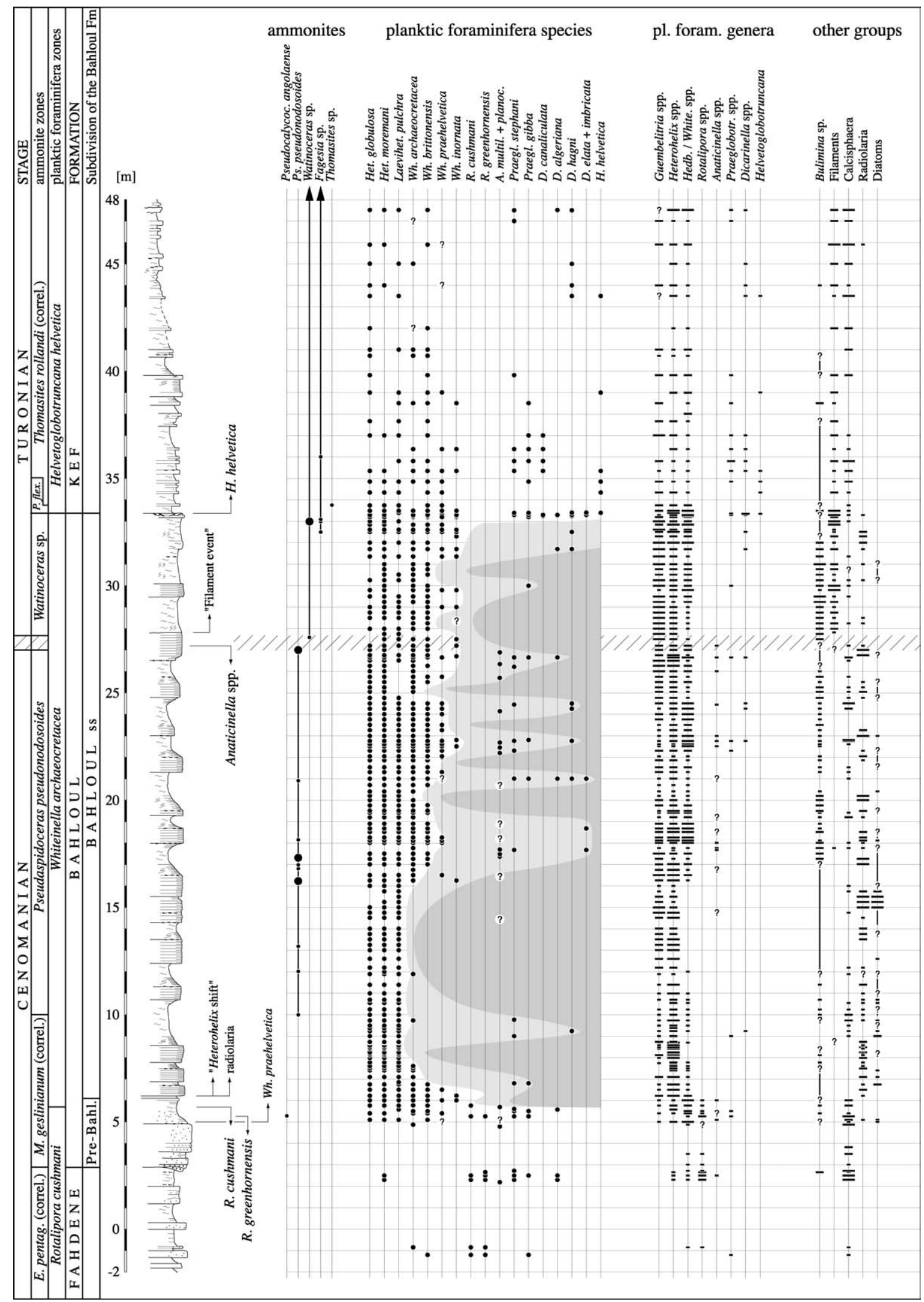


and preservation of isotopically light organic matter (as analyzed by Pratt et al., 1993: p. 346). It is noticeable that it precedes the signature of the drastic paleoenvironmental perturbation which progressively reached intermediate and deep waters inhabited by these keeled planktic foraminifera.

\subsubsection{Radiolarian occurrences}

Radiolarians are common in Bahloul facies. As reported by Caron et al. (1999), radiolarians and diatoms proliferated episodically associated with increased abundance of heterohelicids during deposition of the black laminated limestones of the Bahloul facies. They occur at Bahloul just above the LO of Rotalipora. This event is not so evident at Pueblo where the siliceous microfossils are hard to identify. Nevertheless, at both localities, the peak in radiolarian abundance precedes the "Heterohelix shift". Radiolarian occurrences in both basins are interpreted as the first signals of episodic renewals of nutrientrich oceanic waters. Consequently, they could be used as indicators of an increase of water depth, and of better connections with open oceans.

\subsection{3. "Heterohelix shift"}

Heterohelix moremani and H. globulosa occur in high abundance together with numerous specimens of the genus Whiteinella (W. archaeocretacea and W. brittonensis) at wadi Bahloul, coinciding with the very first organic carbon-rich laminae (Fig. 9a, BLB 6.2 m). At Pueblo (Fig. 4b), the "Heterohelix shift" (from PB $2.20 \mathrm{~m}$, bed 78) is registered slightly above due to a hiatus present just below this level (Meyers et al., 2001). Heterohelicids have simple biserial architecture and globulous chambers. They are primitive morphotypes, living within surface waters as "opportunists", well adapted to rapid changes in temperature, salinity and/or nutrient-level. In this environment, they were favored with respect to the more complex morphotypes living deeper in the water column. The "Heterohelix shift" has been previously recognized by Leckie (1985), Leckie et al. $(1991,1998)$ and then cited by Nederbragt et Fiorentino (1999). More recently Huber et al. (1999) proposed the term "Heterohelix-dominated assemblage" for this event.

In the two sites, this event follows the disappearance of the complex keeled morphotypes: the total extinction of the singlekeeled Rotalipora and the temporary disappearance of double- keeled Dicarinella and Praeglobotruncana. The "Heterohelix shift" is, therefore, part of the faunal turnover observed at this time, particularly at low and mid-latitudes. At high latitudes, this shift is less marked because opportunist species dominate the planktic foraminiferal assemblages throughout Mid-Cretaceous times.

\subsubsection{LO of Anaticinella}

The Anaticinella group has been considered endemic to the WIS during the Late Cenomanian (Eicher, 1969, 1972; Leckie, 1985). Eicher first described this genus as descending from the genus Rotalipora with the species Anaticinella multiloculata evolving from $R$. greenhornensis. Subsequently Leckie (1985) documented a parallel evolution, probably from $R$. cushmani and thus differentiated Anaticinella multiloculata s.s. (descending from R. greenhornensis according Eicher, 1969) and Anaticinella multiloculata s.l. (descending from R. cushmani). In the present study, Anaticinella multiloculata s.l. is considered junior synonym of Anaticinella planoconvexa (Longoria, 1973).

Recently, Desmares et al. (2003) interpreted the emergence of the genus Anaticinella from the genus Rotalipora by the acquisition of a slower growing rate in a population of Rotalipora cushmani and $R$. greenhornensis. This evolution led to modifications in development (loss of the peripheral keel and increase in inflation of chambers) which promoted settings in shallower habitats.

In both the wadi Bahloul and Pueblo sections, A. multiloculata and A. planoconvexa are observed. Anaticinella multiloculata becomes very rare in the uppermost Cenomanian. Its LO seems coeval with the LO of $R$. cushmani. In younger sediments only Anaticinella planoconvexa is common (Leckie, 1985). This species disappears in both sections within the $\mathrm{C} / \mathrm{T}$ precision interval. The presence of Anaticinella group in the Atlantic and Tethys Oceans implies a global adaptation of these species to similar paleoecological modifications. Consequently, if present, the LO of the genus Anaticinella represents one of the most relevant indicator for the C/T boundary. In conjunction with the "Heterohelix shift" and the "filament event," it could be used to subdivide the Whiteinella archaeocretacea Zone (see discussion below, Section 8.1. Turnover).

\footnotetext{
Fig. 9. a, b. Chrono-litho-biostratigraphy of $50 \mathrm{~m}$ of the wadi Bahloul section encompassing the Cenomanian-Turonian boundary interval, showing range distribution of ammonites, calcispheres, radiolarians, planktic foraminifers (a), and fluctuations of $\mathrm{CaCO}_{3} \%, \mathrm{TOC} \%, \delta^{13} \mathrm{Ccarb}$ and $\delta^{18} \mathrm{O} \%$ (b). Lithological legend $(\mathbf{a}, \mathbf{b})$ : hatched surfaces = bentonites; brick pattern = limestone beds; subparallel lines = calcareous marls, more or less laminated; dots = calcarenites; black burrows = bioturbations. Hatched lines (a): mark the precision interval; dark gray shadow indicates the interval when K-species of planktic foraminifera were inhibited; light gray shadow shows the dominance of $r$-species in the planktic foraminiferal assemblage; width of horizontal bars reflects the relative abundance of planktic foraminifera. Geochemistry $(\mathbf{b})$ : clear circles $=$ limestones with more than $80 \% \mathrm{CaCO}_{3}$, suspected of diagenetic alteration; black circles $=$ marly limestones; I, II, III = main peaks on the $\delta^{13} \mathrm{C}$ profile.

Fig. 9. a, b. Chrono-litho-biostratigraphie des 50 mètres de la coupe de l'oued Bahloul qui ont enregistré la limite Cénomanien-Turonien. Distribution stratigraphique des ammonites, des calcisphères, des radiolaires, des foraminifères planctoniques (a), et fluctuations des $\mathrm{CaCO}_{3} \%, \mathrm{TOC}^{2} \%, \delta^{13} \mathrm{Ccarb}$ and $\delta^{18} \mathrm{O} \%$ (b). Légende lithologique $(\mathbf{a}, \mathbf{b})$ : surfaces hachurées $=$ bentonites ; briques $=$ bancs calcaires ; lignes sub-parallèles $=$ marnes plus ou moins laminées ; pointillés = calcarénites ; perforations noires = bioturbations. Lignes hachurées $(\mathbf{a}):$ délimitent l'intervalle de précision ; l'ombrage gris sombre souligne l'intervalle durant lequel les espèces-K des foraminifères planctoniques sont inhibées ; l'ombre gris clair montre l'intervalle durant lequel les espèces- $r$ dominent dans les assemblages de foraminifères planctoniques ; la largeur des barres horizontales reflète l'abondance relative des foraminifères planctoniques. Géochimie (b) : cercles clairs $=$ mesures sur calcaires contenant plus de $80 \%$ de $\mathrm{CaCO}_{3}$, soupçon d'altération diagénétique $;$ cercles noirs $=$ mesures sur calcaires marneux $; \mathbf{I}, \mathbf{I I}$, III $=$ pics principaux sur le profil $\delta^{13} \mathrm{C}$.
} 


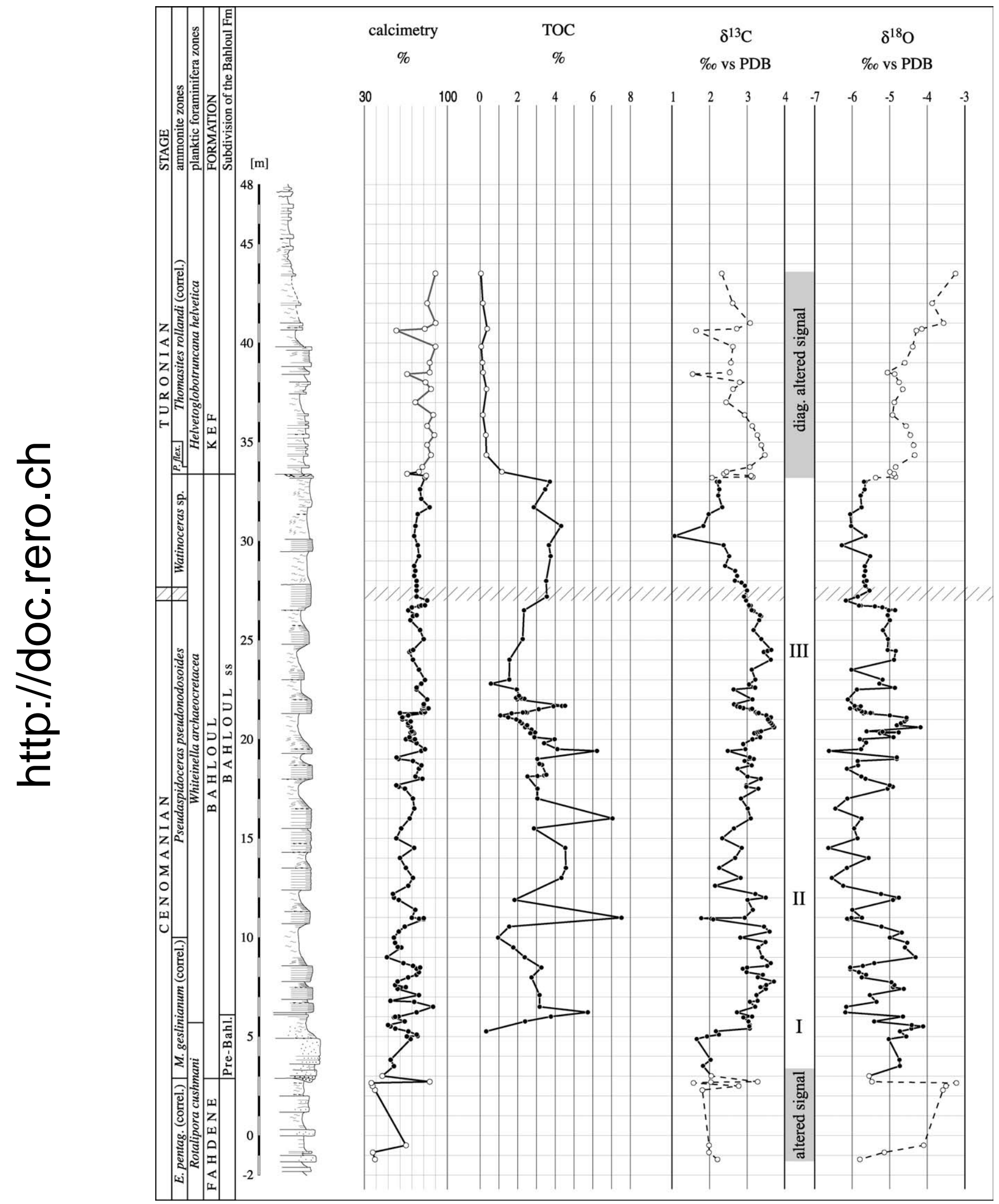

Fig. 9. (continued) 


\subsection{5. "filament event"}

The term "filaments" derives from their aspect in thin sections. This event occurs just above the $\mathrm{C} / \mathrm{T}$ precision interval. Filaments were small bivalves that invaded oceanic nutrientrich environments, because of their short larval-planktic phase (Jefferies and Milton, 1965). In a normal environment, they grew to their adult size, they progressively sank to the bottom where they survived in normal or moderate oxygenated environments. On the two study sites, this downward migration led juveniles into $\mathrm{O}_{2}$-deficient waters. These organisms died in great number before maturity, the two small valves falling wide-open on the sea floor. This explains the occurrence of juvenile bivalve hecatombs, a bio-event that seems to have been global.

At Pueblo, the omnipresence of inoceramids dims the "filament event". In thin sections some rare filaments occur at PB $4.10 \mathrm{~m}$ (in the upper portion of bed 85), but they are more evident at PB $4.60 \mathrm{~m}$ (bed 87, microfacies Fig. 5(2)). At Bahloul this event is obvious, and filaments are observed in great numbers starting at BLB $27.75 \mathrm{~m}$. In central Tunisia, these small bivalves are reported from coeval levels of Bahloul Formation (Robaszynski et al., 1990: p. 221; Nederbragt and Fiorentino, 1999; Accarie et al., 2000).

The "filament event" falls above the $\mathrm{C} / \mathrm{T}$ precision interval at Bahloul and a few $\mathrm{cm}$ above the equivalent level at Pueblo. Consequently, it could serve as a tool for trans-oceanic correlations, particularly if it is coeval with the flood of the genus Mytiloides, more precisely the FO of M. hattini and subsp. (Kauffman et al., 1993: Fig. 3; Bengtson, 1996: p. 70, pt. 4. and p. 71; Kennedy et al., 2000: p. 297). We propose to use the "filament event" as a biomarker for the $\mathrm{C} / \mathrm{T}$ boundary due to its close proximity to this boundary.

\subsubsection{FO H. helvetica and restoration of double-keeled forms}

The first specimens belonging to Whiteinella praehelvetica are observed at BLB $5.50 \mathrm{~m}$ and at $\mathrm{PB}-0.40 \mathrm{~m}$. Therefore this species occurs in both sites before the total extinction of the genus Rotalipora (idem in Huber et al., 1999: p. 401, Black Nose, E Florida; Luciani and Cobianchi, 1999: p. 149, Bonarelli level, Italy). Helvetoglobotruncana helvetica differs from its ancestor Whiteinella praehelvetica in having a true keel throughout all chambers of the last whorl (Caron, 1985: p. 60; Fig. 30, photos 7 and 8).

The FO of $H$. helvetica occurs at wadi Bahloul in BLB $33.25 \mathrm{~m}$ accompanied by dicarinellids and praeglobotruncanids, representing a marked increase in planktic foraminiferal species diversity. The surface of the limestone bed at BLB $33.40 \mathrm{~m}$ is altered by bioturbation structures filled with glauconitic and phosphatic grains, small "filaments" and planktic foraminifers. This surface represents a condensed level, identified at a regional scale. Some specimens of planktic foraminiferal are found within these bioturbation structures, that suggest their downward displacement by about $15 \mathrm{~cm}$. New data from the wadi Bahloul and other sections in Central Tunisia provide evidence for the FO of $H$. helvetica within the Pseudaspidoceras flexuosum Zone (Amédro et al., in press).
At Pueblo, a partial recovery in diversity is observed at PB $5.10 \mathrm{~m} / 5.30 \mathrm{~m}$ (P. flexuosum Zone) where sparse dicarinellids and some $W$. praehelvetica occur. Note that Eicher and Diner (1985) reported H. (Praeglobotruncana) helvetica (without presenting illustrations) at this level. However, Diner (personal communication in Bralower, 1988: p. 303) reported that $H$. helvetica had not been identified in this section. Indeed despite very narrow interval of our sampling, the detailed examination of thin sections and washing residues did not reveal the presence of this taxon at this level. The complete recovery in diversity occurs higher in the section at Pueblo (in PB $6.75 \mathrm{~m}$; base of Mammites nodosoides Zone) with the reappearance of dicarinellids, marginotruncanids and the FO of $H$. helvetica. Eicher and Diner (1989) proposed that the mixing of Tethyan waters with Boreal water masses prevented the northern migration of specialized keeled genera, such as $H$. helvetica. Indeed, the FO of $H$. helvetica at Pueblo corresponds with the peak transgression in the M. nodosoides Zone (Leithold, 1994; West et al., 1998; Sageman et al., 1997, 1998). At a larger scale within the Boreal realm, the FO of $H$. helvetica has not been reported earlier than the $M$. nodosoides Zone (compilation by F. Robaszynski, unpublished data).

Therefore the diachronous FO of $H$. helvetica is here proved, implying that the $\mathrm{FO}$ of $H$. helvetica should not be used as a datum for Tethyan-Boreal correlations.

\subsection{Geochemistry (Fig. 11)}

\subsubsection{Carbon isotopes: $\delta^{13} \mathrm{C}$}

7.4.1.1. Lithology and $\delta^{13} C$. An inverse correlation between $\mathrm{CaCO}_{3}$ content and $\delta^{13} \mathrm{C}$ values exists at the Pueblo section (Pratt, 1985; Pratt et al., 1993). Pratt et al. (1993) suggested the development of an isotopically light carbonate cement. The carbonate cement would have had precipitated from a ${ }^{12} \mathrm{C}$ rich-interstitial fluid due to the production of isotopic light $\mathrm{CO}_{2}$ from decomposition of organic matter during burial. Alternatively, calcareous beds were initially more porous and thus more open to diagenesis than the marly beds. Marly beds with high clay content were more impermeable and consequently, the diagenetic cement would have been preferentially concentrated in the calcareous beds lithified afterward as limestone. Both mechanisms suggest that $\delta^{13} \mathrm{C}$ fluctuations related to marl/limestone alternations could be due to differential cementation occurring during diagenesis. This scenario does not apply to the wadi Bahloul section where $\delta^{13} \mathrm{C}$ values seem to vary independently from lithology.

At the scale of the CTBI, the isotopic signal fluctuates between 1 and 3\%o at Pueblo, and between 2 and 4\%o at wadi Bahloul. At both locations the positive excursion is close to $2 \%$. This variation is consistent with previous results obtained from the carbonate fraction of marine sediments at many sites all over the world (Scholle and Arthur, 1980; Hilbrecht and Hoefs, 1986; Schlanger et al., 1987; Jarvis et al., 1988; Jeans et al., 1991; Peryt and Wyrwicka, 1991; Gale et al., 1993; Paul et al., 1994; Jenkyns et al., 1994; Drzewiecki and Simo, 1997; 


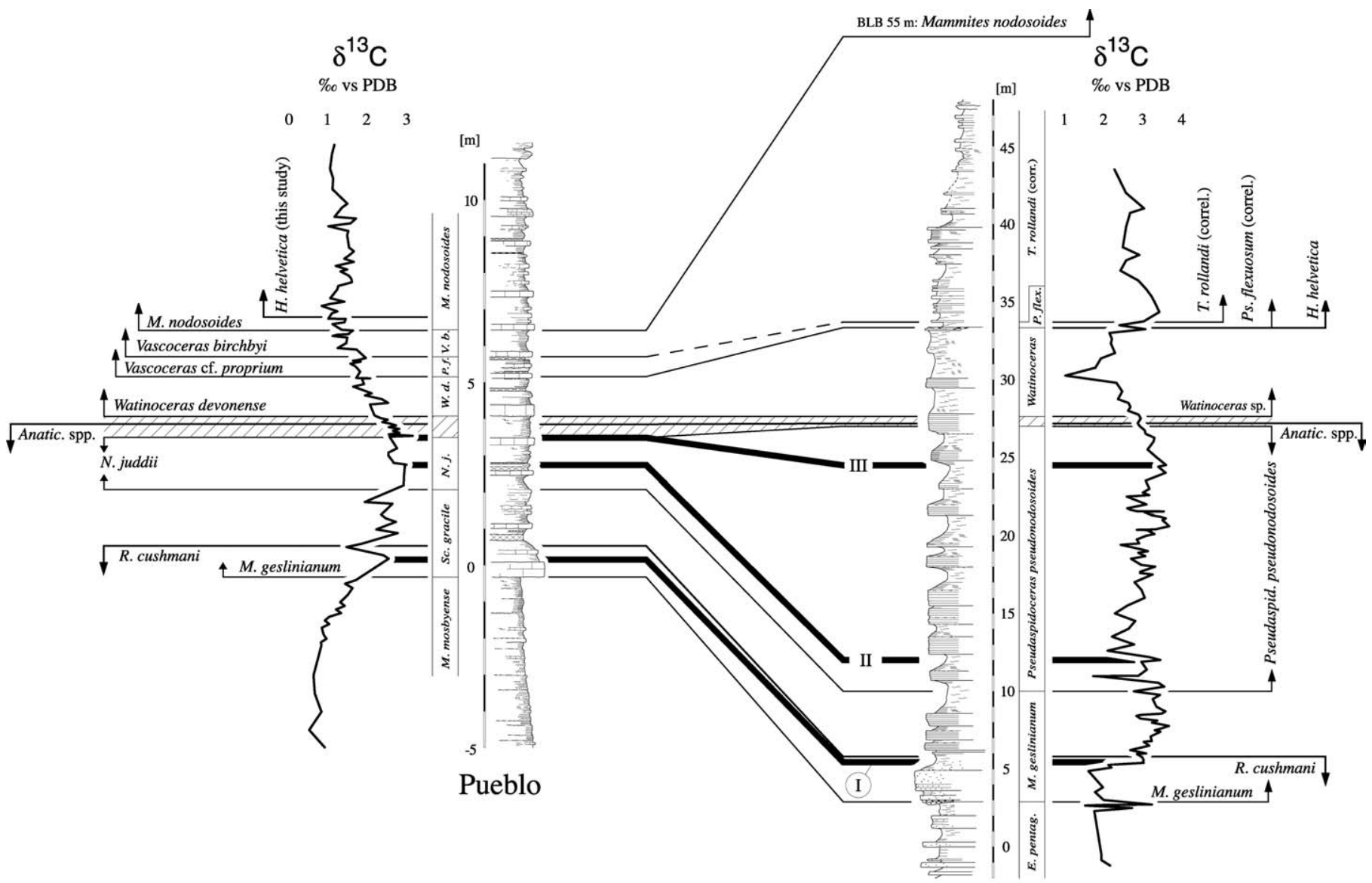

wadi Bahloul

Fig. 11. Long-distance correlation of reference-levels: biostratigraphic (FO \& LO of ammonite and planktic foraminifera marker species) and geochemical datum lines $\left(\delta^{13} \mathrm{C}\right.$ peaks) from the Pueblo section (Colorado) to the wadi Bahloul section (Central Tunisia).

Fig. 11. Corrélation à longue distance des niveaux de référence biostratigraphiques (première et dernière apparition des espèces marqueurs chez les ammonites et les foraminifères planctoniques) et lignes de repères géochimiques (pics $\delta^{13} \mathrm{C}$ ) depuis la coupe de Pueblo (Colorado) jusqu'à la coupe de l'oued Bahloul (Central Tunisia).

Ulicny et al., 1997; and others). The present study records a complex profile of a major $\delta^{13} \mathrm{C}$ positive excursion with significant fluctuations (peaks I, II, III) that can be correlated over a great distance as firstly observed by Pratt and Threlkeld (1984: p. 306). The similarity of the $\delta^{13} \mathrm{C}$ profiles at both Pueblo and at wadi Bahloul indicates that they are independent of lithologic variations, and that the influence of local factors is negligible. The diagenetic overprint seems to be restricted to the scale of limestone/marls alternation, and has a limited effect on the overall $\delta^{13} \mathrm{C}$ profile. Therefore, these $\delta^{13} \mathrm{C}$ profiles record primary chemical changes in the global ocean.

7.4.1.2. TOC and $\delta^{13} C$. At wadi Bahloul, the interval of high TOC values also records high $\delta^{13} \mathrm{C}$ values. The Bahloul facies

Fig. 10. Outcrop and microfacies at wadi Bahloul section (BLB). 1. Field view on top of the Bahloul Formation and passage to Annaba marls of the Kef Formation at BLB 33.40 m. Detailed microfacies: micrite with planktic foraminifera (Whiteinella, Heterohelix) and abundant "filaments". Helvetoglobotruncana helvetica first occurs in correspondence of this level. 2. Field view of rhythmic bedded couplets from BLB $21 \mathrm{~m}$ to BLB $29 \mathrm{~m}$. Detailed microfacies of marls at BLB $22.50 \mathrm{~m}$ : wackestone with sparse Heterohelix and Whiteinella. 3. Field view of thinly bedded dark limestones (cm), with fine laminae (mm), from BLB 21.50 to $22.00 \mathrm{~m}$. Detailed microfacies of the inframillimetric laminae: Heterohelix blooms distributed as white levels within dark matrix mainly composed of organic-rich small pellets. 4. Field view on the base of the wadi Bahloul section (from BLB $5.00 \mathrm{~m}$ to BLB $12.00 \mathrm{~m}$ ), just above the bioclastic chenal. Detailed field view of transition from marls (BLB $5.0 \mathrm{~m}$ ) to first dark laminated limestones (BLB $6.0 \mathrm{~m}$ ).

Fig. 10. Affleurement et microfaciès à la coupe de l'oued Bahloul (BLB). 1. Vue de terrain sur le sommet de la Formation Bahloul et le passage aux marnes de l'Annaba de la Formation El Kef au banc BLB 33,40 m. Microfaciès détaillé : micrite à foraminifères planctoniques (Whiteinella, Heterohelix) et abondants « filaments ». Helvetoglobotruncana helvetica apparaît pour la première fois à ce niveau. 2. Vue de terrain de l'alternance rythmique des couplets de bancs de BLB $21 \mathrm{~m}$ à BLB $29 \mathrm{~m}$. Microfaciès détaillé des marnes au banc BLB 22,50 m : wackestone à rares Heterohelix et Whiteinella. 3. Vue de terrain des calcaires noirs en petits bancs $(\mathrm{cm})$, à fines lamines (mm), de BLB 21,50 m à BLB 22,00 m. Microfaciès détaillé des lamines infra-millimétriques : proliférations des Heterohelix distribués en lignes claires dans une matrice sombre composée principalement de petites pelotes fécales riches en matière organique. 4 . Vue de terrain sur la base de la coupe de l'oued Bahloul (de BLB 5,00 m à BLB 12,00 m), juste au-dessus du chenal bioclastique. Vue de terrain détaillée sur la transition entre les marnes (BLB $5,0 \mathrm{~m}$ ) et les premiers calcaires noirs laminés (BLB 6,0 m). 
s.s. has TOC values up to $7 \%$. This sub-unit is the equivalent of the OAE2, which is often characterized by organic-rich sediments in the pelagic realm. According to several authors (Schlanger and Jenkyns, 1976; Scholle and Arthur, 1980; Herbin et al., 1986; Schlanger et al., 1987; Arthur et al., 1990; and others) this high accumulation of organic matter in marine sediments is responsible for the $\delta^{13} \mathrm{C}$ positive excursion at the CTBI.

The correlation between TOC and $\delta^{13} \mathrm{C}$ values observed at wadi Bahloul is indicative of good preservation of the primary organic matter in the section. Both the preservation of high TOC content, modulated by lithology, and the high $\delta^{13} \mathrm{C}$ values may reflect a global oceanic event.

In contrast, at Pueblo the first increase in TOC values is delayed relative to the first positive shift in $\delta^{13} \mathrm{C}$ values (peak I). We suggest that the preservation of TOC in this interval is linked to local processes as shown by current-related sedimentary structures formed in oxygenated conditions. From PB $2.5 \mathrm{~m}$ to $4.5 \mathrm{~m}$ (bed $79-87$ ), TOC and $\delta^{13} \mathrm{C}$ profiles at the Pueblo section resemble those at wadi Bahloul with high TOC values and $\delta^{13} \mathrm{C}$ values shifting in parallel.

Above peak III, local environmental conditions similar to those inferred for the deposition of sediments below PB $2.5 \mathrm{~m}$ seem to have occurred.

7.4.1.3. Placement of the $\delta^{13} C$ peaks. As discussed before, the $\delta^{13} \mathrm{C}$ records of Pueblo and wadi Bahloul record similar features (Fig. 11). These are, in stratigraphic order, from bottom to top:

The $\delta^{13} \mathrm{C}$ peak I placed in the lower part of the Sciponoceras gracile Zone of the US Western Interior and in the equivalent Metoicoceras geslinianum Zone of Central Tunisia.

The $\delta^{13} \mathrm{C}$ peak II located near the base of the Neocardioceras juddii Zone in the Western Interior and in the equivalent Pseudaspidoceras pseudonodosoides Zone of Central Tunisia.

At Pueblo, the $\delta^{13} \mathrm{C}$ peak III is observed close to the base of bed 85 (sample PB $3.55 \mathrm{~m}$ ). This corresponds to the top of the $N$. juddii Zone. At wadi Bahloul, the $\delta^{13} \mathrm{C}$ peak III is precisely at the level BLB $24.50 \mathrm{~m}$, near the top of the P. pseudonodosoides Zone. In both locations, peak III is below the $\mathrm{C} / \mathrm{T}$ boundary.

However, we encountered some problems in the placement of peak III at the Pueblo section (Fig. 4c). This peak corresponds to the last high value of Pratt's plateau $\mathrm{C}$, before the descending trend. The original $\delta^{13} \mathrm{Corg}$ data (Fig. 12) were reported with the $\delta^{13} \mathrm{Corg}$ plateau $\mathrm{C}$ extending from bed 76 to bed 85 . The last high value of plateau $\mathrm{C}$ was located in the middle of bed 85 , just above the $\mathrm{C} / \mathrm{T}$ boundary which was placed then in bed 84 (Pratt, 1982; Pratt and Threlkeld, 1984; Pratt, 1985). Subsequently, Gale et al. (1993) published a composite figure where the lithological and faunal succession from Cobban (1985) was combined with the $\delta^{13}$ Corg data from Pratt and Threlkeld (1984). In this figure, the prominent information is that the base of bed 86 contains the FO of Watinoceras devonense and represents a new position for the $\mathrm{C} / \mathrm{T}$ boundary. However, we can observe that the last high value of the plateau
C is not set in bed 85 , but at the base of bed 87 , a shifting which brings it above the new position of the $\mathrm{C} / \mathrm{T}$ boundary. Other subsequent publications using the same figure, including Bengtson (1996) and Kennedy et al. (2000), have likewise misplaced the end of the $\delta^{13}$ Corg plateau C.

In summary, according to this study, in both US Western Interior and Central Tunisia areas, the $\delta^{13} \mathrm{C}$ peak III is placed, not above the C/T boundary as indicated by Bengtson (1996), but just below the lower limit of the Turonian stage (below the base of the $\mathrm{C} / \mathrm{T}$ precision interval).

This $\delta^{13} \mathrm{C}$ feature, which is indirectly dated using the ammonite biostratigraphy, is a strong marker for the $\mathrm{C} / \mathrm{T}$ boundary as well as a powerful tool for correlation.

\section{Interpretation}

\subsection{Planktic foraminifera turnover (Fig. 13)}

In the approximately 1-million-year interval encompassing the events associated with the $\mathrm{C} / \mathrm{T}$ boundary interval, changes in planktic foraminiferal assemblages (i.e., relative abundance and species diversity) reflect paleoenvironmental perturbations. At both Pueblo and wadi Bahloul sections, planktic foraminifera dominate the microfossil assemblages, as observed in thin sections and washed residues, and provide valuable information. Comparison between planktic foraminifera ranges and the rich record of ammonites provides an important framework for interbasinal correlations. The whole of planktic foraminiferal event which occurred at this time can be identified as a major global turnover.

\subsubsection{Turnover structure}

At a large time-scale. Before the turnover event, high diversity prevailed in the trochospiral keeled species (belonging to the genera Rotalipora, Dicarinella, Praeglobotruncana and Whiteinella pro parte) that were deep and intermediate water dwellers, adapted to oligotrophic stable nutrient levels. Named "equilibrium" species, these complex morphotypes correspond to the "K-selected" species of biologists (Mac Arthur and Wilson, 1967). They dominated the assemblages throughout the R. cushmani Zone. During this high diversity period, other less complex planktic foraminifera, characterized by non-keeled trochospiral and biserial morphotypes (Whiteinella pro parte, Hedbergella, Heterohelix, Guembelitria) developed in surface and intermediate waters. Although they never dominated the assemblage at this time, their capacity for adaptation remained high.

The turnover starts at the studied sections with the onset of paleoenvironmental perturbations, which led to the demise of complex morphotype species and furthered the proliferation of primitive morphotypes (Caron and Homewood, 1982). These correspond to the " $r$ selected" species of biologists. They were unaffected because of their extreme tolerance to fluctuations of nutrient levels, salinity and temperature in surface waters. This association of opportunists is characterized by high abundance of specimens and low species-diversity. 


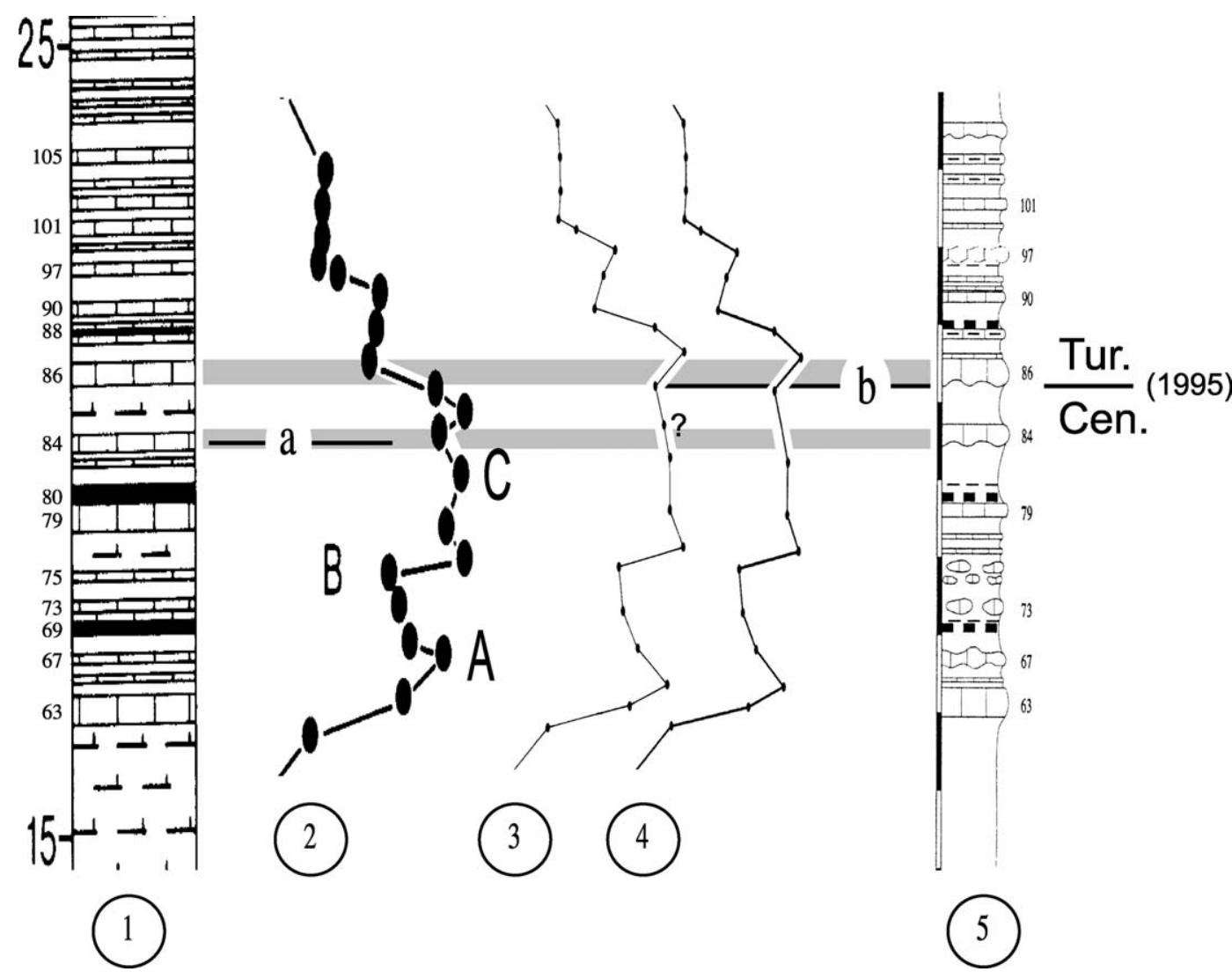

Fig. 12. Comparison of $\delta^{13} \mathrm{C}$ curves published for the Pueblo section. 1, lithologic profile of the borehole, PU-79-Pueblo core in Pratt (1982), Pratt (1984) and Pratt and Threlkeld (1984). 2, $\delta^{13}$ Corg curve of Pratt and Threlkeld (1984), and Pratt (1985), with details of the positive excursion: $A=$ first peak; B = a brief decrease; $\mathrm{C}=$ plateau of values before the descending phase. 3, $\delta^{13} \mathrm{Corg}$ curve of Pratt and Threlkeld (1984) reproduced in Gale et al. (1993) referred to as "original from Pratt and Threlkeld (1984) and from Pratt et al. (1993)". Note the additional point marked here (?) that causes a stretching of the original curve. 4, $\delta^{13}$ Corg curve reproduced in Kennedy et al. (2000: Fig. 9). Note that the additional point has been removed whereas the stretching remains. 5, lithologic profile of the Pueblo section, published by Cobban (1985), and by Kennedy and Cobban (1991). Dark horizontal lines: a = early position of the C/T boundary in bed 84 according Cobban and Scott (1972), as published in Pratt (1982, 1984, 1985) and Pratt and Threlkeld (1984); and $\mathbf{b}=$ position of the C/T boundary at the base of bed 86 as defined by Kennedy and Cobban (1991). Thick light grey bands underline lithologic correlation of beds 84 and 86 .

Fig. 12. Comparaison des courbes de $\delta^{13} \mathrm{C}$ publiées pour la coupe de Pueblo. 1, profil lithologique du puits PU-79-Pueblo publié par Pratt (1982), Pratt (1984) et Pratt et Threlkeld (1984). 2, courbe du $\delta^{13}$ Corg publiée par Pratt et Threlkeld (1984), et Pratt (1985), avec les détails de l'excursion positive : A = premier pic ; B = brève diminution des valeurs ; $\mathrm{C}=$ plateau des valeurs élevées avant la phase de descente. 3, courbe du $\delta^{13}$ Corg de Pratt et Threlkeld (1984) reproduite par Gale et al. (1993) rapportée comme « l'original de Pratt et Threlkeld (1984) et de Pratt et al. (1993) ». Noter le point ajouté (marqué ici -?-) qui a causé un étirement de la courbe originale. 4, courbe du $\delta^{13}$ Corg reproduite par Kennedy et al. (2000 : Fig. 9). Noter que le point ajouté a été ici enlevé alors que l'étirement est conservé. 5, profil lithologique de la coupe de Pueblo, publié par Cobban (1985), et par Kennedy et Cobban (1991). Lignes noires horizontales : $\mathbf{a}=$ position initiale de la limite C/T boundary dans le banc 84 selon Cobban et Scott (1972), comme publiée par Pratt $(1982,1984,1985)$ et Pratt et Threlkeld (1984); et $\mathbf{b}=$ position de la limite C/T à la base du banc 86 ainsi qu'elle a été définie par Kennedy et Cobban (1991). Bandes gris clair larges soulignent les corrélations lithologiques du banc 84 et du banc 86 .

The turnover ends with the reappearance of complex keeled morphotypes (K-selected), including H. helvetica. The high species-diversity points to the recovery of a stable oligotrophic environment throughout the oceans. According to our correlation we suggest that the end of the turnover was diachronous. We interpret this to reflect the pattern of circulation of oceanic water masses, which depended on the paleogeographic situation of each site.

At a lower time-scale, the turnover developed within the time-envelope of the $W$. archaeocretacea PRZ. Several bioevents occurred, which structured the turnover.

The Cenomanian part: the total disappearance of the genus Rotalipora marked the onset of the turnover.

Whiteinella assemblage increased in abundance in correspondence of the Heterohelix shift. This association of inflated morphotypes typifies the $W$. archaeocretacea PRZ. At about the same time, large morphotypes belonging to the genera $D i$ carinella, Praeglobotruncana and Anaticinella vanished temporarily (dark gray shading in Figs. 4b and 9a). Episodic reappearances of these complex species (light gray shading in Figs. $4 \mathrm{~b}$ and $9 \mathrm{a}$ ) are remarkable short events, especially at the wadi Bahloul section where they can be observed within the marly layers only. At the Pueblo section, these reoccurrences are more sporadic. The genus Anaticinella, on the contrary, is common (Eicher, 1972; Wonders, 1980; Leckie, 1985).

Another important event characterizes this episode: the presence of some radiolarians at Pueblo (Fig. 4b), and the high abundance of radiolarians and diatoms at wadi Bahloul (Fig. 9a) preceding the "Heterohelix shift" as an early signal of increasing nutrient level in surface waters. 


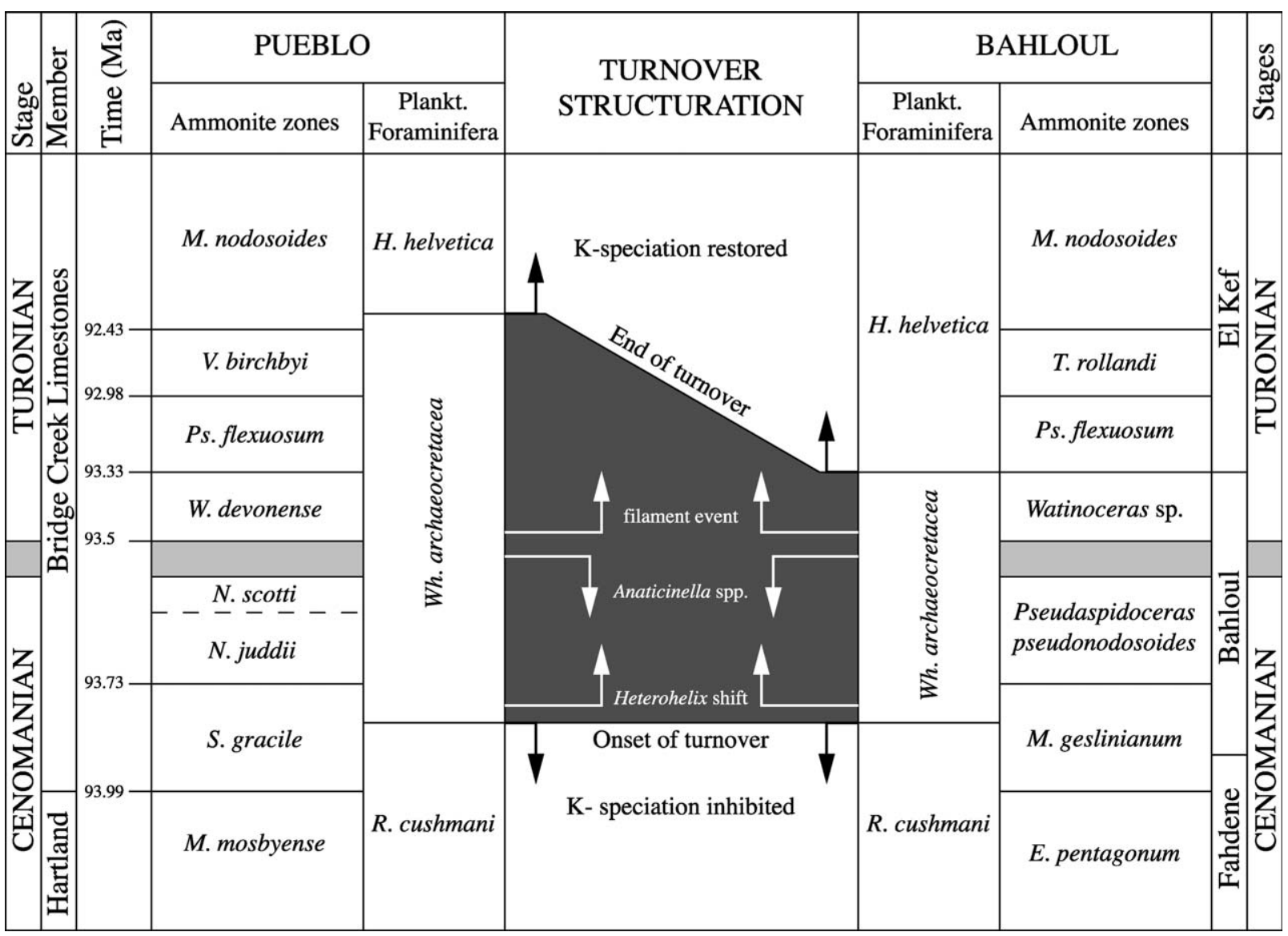

Fig. 13. Planktic foraminiferal turnover during the Cenomanian-Turonian boundary interval at Pueblo and wadi Bahloul. Structure and diachroneity of this turnover relative to the chronostratigraphy and the ammonite zonation. Note position of the three bio-events that structure this interval: Heterohelix shift, LO of Anaticinella sp. and "filament" event. The light gray shadow marks the precision interval; dark gray shadow marks the lengths of dominance time of $r$-speciation that correspond to the diachronism of the Whiteinella archaeocretacea Zone from Pueblo to Bahloul area.

Fig. 13. Le renversement (turnover) chez les foraminifères planctoniques pendant l'intervalle couvrant la limite Cénomanien-Turonien à Pueblo et à l'oued Bahloul. Structure et diachronisme de ce renversement basés sur la chronostratigraphie et les zones d'ammonites. Noter la position des 3 événements biologiques qui structurent cet intervalle : le retour en masse des Heterohelix, la dernière présence des spécimens d'Anaticinella spp. et l'événement à « filaments ». L'ombre gris clair marque l'intervalle de précision ; l'ombre gris sombre souligne les durées de la dominance de la spéciation-r qui correspondent au diachronisme de la Zone à Whiteinella archaeocretacea Zone de Pueblo à Bahloul.

The C/T precision interval: the disappearance of the last representative of Anaticinella planoconvexa at both localities is a new datum, and the most useful marker for the $\mathrm{C} / \mathrm{T}$ boundary.

The Turonian part: the dominance of opportunistic species (abundant Heterohelix and Whiteinella) extended without any change through the $\mathrm{C} / \mathrm{T}$ precision interval until the end of the turnover.

The recovery of species diversity is delayed at the Pueblo section compared to wadi Bahloul. Full recovery, characterized by high species diversity including $H$. helvetica, occurred at wadi Bahloul within the ammonite Pseudaspidoceras flexuosum Zone. The recovery proceeded in two episodes at Pueblo. The first episode is coeval with that at wadi Bahloul but less marked. Full recovery occurred at Pueblo only within Mammites nodosoides.

\subsubsection{Turnover definition}

This turnover represents in both localities the same planktic foraminifera bio-event. It reflects a rapid increase in the pro- ductivity of surface waters. Due to short and shallow life-cycle $(r$-speciation) and high reproductive potential, simple and poorly evolved species could rapidly adapt to nutrient, temperature and salinity fluctuations. Complex morphotypes, with longer and deeper life-cycle (K-speciation), could not adapt and disappear during this time.

The structure of the turnover is comparable in the two sites. The early proliferation of $r$-species (Heterohelix and Whiteinella), characteristic of this bio-event, is marked by steps recording incomplete attempts of recovery of K-species. The fluctuations in the recovery of $\mathrm{K}$-species are well marked at wadi Bahloul in the upper part of the Cenomanian and at Pueblo in the base of the Turonian.

However, the duration of the turnover is very different from wadi Bahloul to Pueblo. The beginning seems synchronous at the two sites, underlined by the disappearance of $R o$ talipora which is correlated by equivalent ammonite zones (S. gracile/M. geslinianum Zones). The restoration of diversity is indicated by the reappearance of the keeled species, escorted 
by the FO of $H$. helvetica. This species appears earlier at wadi Bahloul (coeval with the P. flexuosum Zone) than at Pueblo (coeval with $M$. nodosoides Zone). Constrained by the ammonite biostratigraphy as calibrated in Hardenbol et al. (1998), the duration of this turnover (Fig. 13) is estimated to be $800 \mathrm{ky}$ at wadi Bahloul and about 1.5 My at Pueblo. Therefore, the Whiteinella archaeocretacea PRZ is shorter in the Tethyan Ocean than in the Western Interior Basin and Helvetoglobotruncana helvetica can no longer be an index-species for Tethyan-Boreal Ocean correlations.

\section{Conclusions: high-resolution stratigraphy during $\mathrm{C} / \mathrm{T}$ boundary interval (Figs. 11 and 14)}

The two sections wadi Bahloul and Pueblo are complementary. The biostratigraphic framework is drawn by ammonites, independently of the main peaks in the $\delta^{13} \mathrm{C}$ profiles. Accordingly, the ammonite stratigraphy shows that the $\delta^{13} \mathrm{C}$ peaks are additional and powerful correlation tools for high-resolution stratigraphy of the $\mathrm{C} / \mathrm{T}$ boundary interval. Combination of multiple proxies, including stable isotopes, planktic foraminifera

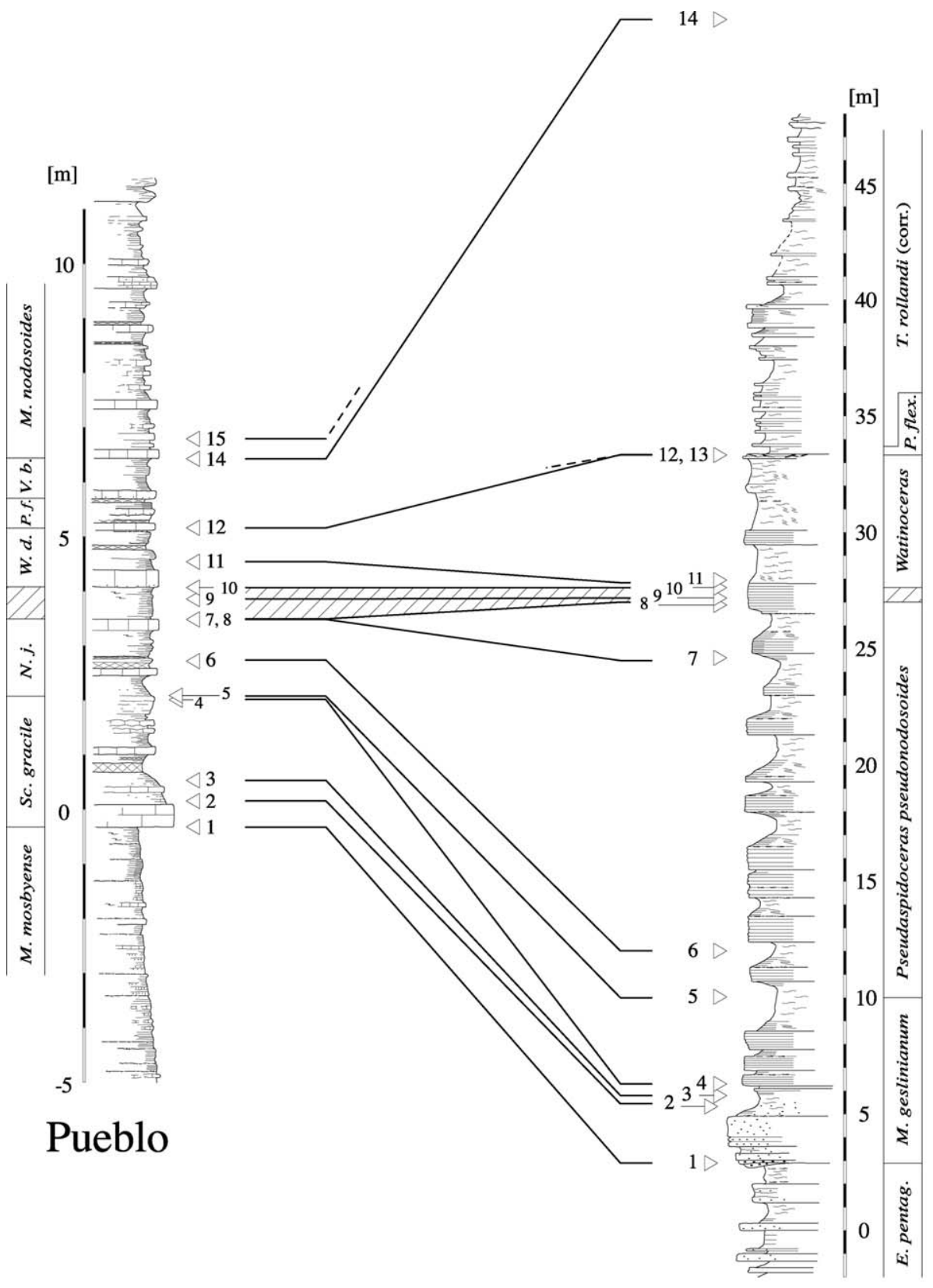

\section{wadi Bahloul}

Fig. 14. High-resolution stratigraphy of the $\mathrm{C} / \mathrm{T}$ boundary interval with the 15 events identified in this study and useful for correlation; set in stratigraphic order. Fig. 14. Stratigraphie à haute résolution de l'intervalle couvrant la limite Cénomanien-Turonien avec les 15 événements identifiés dans cette étude, outils de corrélation, placés dans l'ordre stratigraphique. 
and other bio-events, improves our understanding of the complex stratigraphy of the CTBI.

This study proposes useful events to identify the CTBI. They are in relative chronologic order, from oldest to younger: 1. FO of the ammonite Sciponoceras gracile-Metoicoceras geslinianum assemblage-Zone, 2. $\delta^{13} \mathrm{C}$ peak I, 3. LO Rotalipora cushmani, 4. the "Heterohelix shift", 5. FO of the ammonites Pseudaspidoceras pseudonodosoides and Neocardioceras juddii, 6. $\delta^{13} \mathrm{C}$ peak II, 7. $\delta^{13} \mathrm{C}$ peak III, 8. LO Cenomanian ammonites (P. pseudonodosoides and N. juddii), 9. LO Anaticinella, 10. FO Turonian ammonites (Watinoceras devonense, base of the Turonian stage), 11. the "filament event", 12. FO Pseudaspidoceras flexuosum, 13. FO Tethyan Helvetoglobotruncana helvetica, 14. FO Mammites nodosoides, 15. FO Western Interior $H$. helvetica.

These stratigraphic elements would allow to place with precision the $\mathrm{C} / \mathrm{T}$ boundary in marine series, mainly in the Tethyan realm where paleontological records are poor or devoid of ammonites. The more prominent of these proxies are:

- The last occurrence of Anaticinella within the $\mathrm{C} / \mathrm{T}$ precision interval and the "filament event" immediately at the top of this interval.

- The $\delta^{13} \mathrm{C}$ peak III, identified at the top of the last ammonite zone of the Late Cenomanian ( $N$. juddii in the Western Interior and P. pseudonodosoides in Central Tunisia).

A global turnover among planktic foraminifera frames the CTBI. This biological event is characterized by the disappearance of K-species (Rotalipora) and dominance of $r$-species (Heterohelix and Whiteinella), defining the W. archaeocretacea Partial Range Zone. Local paleoenvironmental conditions influenced the turnover structure and consequently the $W$. archaeocretacea PRZ may have a variable duration. This study demonstrates that Helvetoglobotruncana helvetica appears earlier in the Tethyan Ocean (Pseudaspidoceras flexuosum Zone) than in the Western Interior Basin (Mammites nodosoides Zone). The diachroneity of the FO of $\mathbf{H}$. helvetica from warm Tethyan to cold Boreal water masses is an important result with relevant negative consequence for correlations at the global scale.

\section{Acknowledgments}

This research was carried out by S.D. during his post-doc at the Geological Institute of the University of Fribourg supported by the Swiss National Science Foundation (research grant no. 21-55626.98, M.C. requerant and E.B. co-requerant). We would like to thank François Baudin (University of Paris-VI) for the analyses of TOC and Steve Burns (University of Bern) for the stable isototope analyses of $\delta^{13} \mathrm{C}$ and $\delta^{18} \mathrm{O}$. We are grateful to the reviewers, Danièle Groshény and Serge Ferry for providing valuable comments that improved the manuscript.

\section{References}

Accarie, H., Emmanuel, L., Robaszynski, F., Baudin, F., Amédro, F., Caron, M., Deconinck, J.F., 1996. La géochimie isotopique du carbone $\left(\delta^{13} \mathrm{C}\right)$ comme outil stratigraphique. Application à la limite Cénomanien-Turonien en Tunisie centrale. Comptes Rendus de l'Académie des Sciences de Paris (2a) 322, 579-586.

Accarie, H., Robaszynski, F., Amédro, F., Caron, M., Zagrarni, M.F., 2000. Stratigraphie événementielle au passage Cénomanien-Turonien dans le secteur occidental de la plate-forme de Tunisie Centrale (Formation Bahloul, région de Kalaat Senan). Annales des Mines et de la Géologie, Tunisie 40, 63-80.

Amédro, F., Accarie, H., Robaszynski, F., (in press). Position de la limite Cénomanien-Turonien dans la Formation Bahloul de Tunisie centrale : apports intégrés des ammonites et des isotopes du carbone $\left(\delta^{13} \mathrm{C}\right)$. Eclogae Geologicae Helvetiae.

Arthur, M.A., Jenkyns, H.C., Brumsack, H.J., Schlanger, S.O., 1990. Stratigraphy, geochemistry, and paleoceanography of organic carbon-rich Cretaceous sequences. In: Ginsburg, R.N., Beaudoin, B. (Eds.), Cretaceous Ressources, Events and Rhythms: Background and Plans for Research. NATO ASI series. pp. 75-119.

Bengtson, P., 1996. The Turonian stage and substage boundaries. In: Rawson, P.F., Dhont, A.V., Hancock, J.M., Kennedy, W.J. (Eds.), Proceedings « Second International Symposium on Cretaceous Stage Boundaries » Brussels 1995. Bulletin de l'Institut Royal des Sciences Naturelles de Belgique, pp. 69-79 (66 suppl.).

Ben Haj Ali, N., Razgallah, S., Ben Haj Ali, M., Kennedy, J.W., 1994. La Formation Bahloul dans sa localité-type : précisions stratigraphiques basées sur les ammonites et les foraminifères planctoniques. Notes du Service Géologique de Tunisie 60, 35-58.

Bralower, T.J., 1988. Calcareous nannofossil biostratigraphy and assemblages of the Cenomanian-Turonian boundary interval: implications for the origin and timing of oceanic anoxia. Paleoceanography 3, 275-316.

Burollet, P.F., 1956. Contribution à l'étude stratigraphique de la Tunisie Centrale. Annales des Mines et de la Géologie, Tunisie 18, 1-345.

Burollet, P.F., Dumestre, A., Keppel, D., Salvador, A., 1954. Unités stratigraphiques en Tunisie centrale. $19^{\mathrm{e}}$ Congrès géologique International d'Alger 21, 243-254.

Burollet, P.F., Robaszynski, F., 1991. Les événements de la limite Cénomanien-Turonien en Tunisie centrale : la Formation Bahloul. Géologie alpine $67,3-42$.

Caldwell, W.G.E., Diner, R., Eicher, D.L., Fowler, S.P., North, B.R., Stelck, C. R., von Holdt Wilhem, L., 1993. Foraminiferal biostratigraphy of Cretaceous marine cyclothèmes. In: Caldwell, W.G.E., Kauffman, E.G. (Eds.), Evolution of the Western Interior Basin. Geological Association of Canada, Special Paper 39, pp. 477-520.

Caldwell, W.G.E., Kauffman, E.G., 1993. Evolution of the Western Interior Basin. Geological Association of Canada, Special Paper 39 1-680.

Caron, M., 1985. Cretaceous planktic foraminifera. In: Bolli, H.M., Saunders, J.B., Perch-Nielsen, K. (Eds.), Plankton Stratigraphy. Cambridge University Press, pp. 17-86.

Caron, M., Homewood, P., 1982. Evolution of early planktic foraminifers. Marine Micropaleontology 7, 453-462.

Caron, M., Robaszynski, F., Amédro, F., Baudin, F., Deconinck, J.-F., Hochuli, P., Von Salis-Perch Nielsen, K., Tribovillard, N., 1999. Estimation de la durée de l'événement anoxique global au passage Cénomanien-Turonien. Approche cyclostratigraphique dans la Formation Bahloul en Tunisie centrale. Bulletin de la Société géologique de France 170, 145-160.

Chancellor, G.R., Kennedy, W.J., Hancock, J.M., 1994. Turonian ammonite faunas from Central Tunisia. Special papers in Palaeontology 50, 1-118.

Cobban, W.A., 1985. Ammonite record from Bridge Creek member of Greenhorn limestone at Pueblo reservoir State recreation area, Colorado. In: Pratt, L.M., Kauffman, E.G., Zelts, F.B. (Eds.), Fine-grained Deposits and Biofacies of the Cretaceous Western Interior Seaway: Evidence of Cyclic Sedimentary Processes. SEPM, 2nd Annual Meeting, Golden, CO, Field Trip Guide-book 4, pp. 135-138. 
Cobban, W.A., 1988. The Upper Cretaceous ammonite Watinoceras Warren in the Western Interior of the United States. United States Geological Survey, Bulletin 1788, 1-15.

Cobban, W.A., Hook, S.C., Kennedy, W.J., 1989. Upper Cretaceous rock and ammonite faunas of southwestern New Mexico. New Mexico Bureau Mines and Mineral Resources, memoir 45 1-137.

Cobban, W.A., Scott, G.R., 1972. Stratigraphy and ammonite fauna of the Graneros Shale and Greenhorn Limestone near Pueblo, Colorado. United States Geological Survey Professional Paper 645 1-108.

Desmares, D., Grosheny, D., Beaudoin, B., 2003. Hétérochronies du développement sensu Gould chez les foraminifères cénomaniens : exemple de néoténie dans le bassin du Western Interior américain. Comptes rendus Palevol 2, 587-595.

Drzewiecki, P.A., Simo, J.A., 1997. Carbonate platform drowning and oceanic events on a mid-Cretaceous carbonate platform, south-central Pyrenees, Spain. Journal of Sedimentary Research 67, 698-714.

Eicher, D.L., 1965. Foraminifera and biostratigraphy of the Graneros Shale. Journal of Paleontology 39, 875-909.

Eicher, D.L., 1969. Cenomanian and Turonian planktonic foraminifera from the Western Interior of the United States. In: Brill, E.J. (Ed.), Ist International Conference on Planktonic Microfossils, Geneva Switzerland, 1967. Netherlands, Proceedings 2, Leiden, pp. 163-174.

Eicher, D.L., 1972. Phylogeny of the late Cenomanian planktonic foraminifer Anaticinella multiloculata (Morrow). Journal of Foraminiferal Research 2, 184-190.

Eicher, D.L., Diner, S.R., 1985. Foraminifera as indicators of water mass in the Cretaceous Greenhorn Sea, Western Interior. In: Pratt, L.M., Kauffman, E.G., Zelts, F.B. (Eds.), Fine-grained Deposits and Biofacies of the Cretaceous Western Interior Seaway: Evidence of Cyclic Sedimentary Processes. SEPM, 2nd Annual Meeting, Golden, CO, Field Trip Guide-book 4, pp. $60-71$.

Eicher, D.L., Diner, S.R., 1989. Origin of the Cretaceous Bridge Creek cycles in the Western Interior, United States. Palaeogeography, Palaeoclimatology, Palaeoecology 74, 127-146.

Eicher, D.L., Worstell, P., 1970. Cenomanian and Turonian foraminifera from the Great Plains, United States. Micropaleontology 16, 269-324.

Elder, W.P., 1985. Biotic patterns across the Cenomanian-Turonian extinction boundary near Pueblo, Colorado. In: Pratt, L.M., Kauffman, E.G., Zelts, F. B. (Eds.), Fine-grained Deposits and Biofacies of the Cretaceous Western Interior Seaway: Evidence of Cyclic Sedimentary Processes. SEPM, 2nd Annual Meeting, Golden, CO, Field Trip Guide-book 4, pp. 157-169.

Elder, W.P., Kirkland, J.I., 1985. Stratigraphy and depositional environments of the Bridge Creek Limestone Member of the Greenhorn Formation at Rock Canyon Anticline near Pueblo, Colorado. In: Pratt, L.M., Kauffman, E.G., Zelt, F.B. (Eds.), Fine-grained Deposits and Biofacies of the Cretaceous Western Interior Seaway: Evidence of Cyclic Sedimentary Processes. SEPM, 2nd Annual Meeting, Golden, CO, Field Trip Guide-book 4, pp. 122-134.

Fournié, D., 1978. Nomenclature lithostratigraphique des séries du Crétacé supérieur au Tertiaire de Tunisie. Bulletin des Centres de Recherche Exploration-Production Elf Aquitaine, Pau 2, 97-148.

Gale, A.S., Jenkyns, H.C., Kennedy, W.J., Corfield, R.M., 1993. Chemostratigraphy versus biostratigraphy data from around the Cenomanian-Turonian boundary. Journal of Geological Society of London 150, 29-32.

Hardenbol, J., Thierry, J., Farley, M., Jacquin, T., De Graciansky, P.C., Vail, P. R., 1998. Chart 5 of Mesozoic and Cenozoic sequence chronostratigraphic framework of European basins Cretaceous sequence chronostratigraphy. In: De Graciansky, P.C., Hardenbol, J., Jacquin, T., Vail, P.R. (Eds.), Mesozoic and Cenozoic Sequence Stratigraphy of European Basins. SEPM, special publication 60, pp. 764-765.

Herbin, J.P., Montadert, L., Müller, C., Gomez, R., Thurow, J., Wiedmann, J., 1986. Organic-rich sedimentation at the Cenomanian-Turonian boundary in oceanic and coastal basins in the North Atlantic and Tethys. In: Summerhayes, C.P., Shackleton, N.J. (Eds.), North Atlantic Palaeoceanography. Geological Society, Special Publication 21, pp. 389-422.

Hilbrecht, H., Hoefs, J., 1986. Geochemical and palaeontological studies of the $\delta^{13} \mathrm{C}$ anomaly in Boreal and North Tethyan Cenomanian-Turonian se- diments in Germany and adjacent areas. Palaeogeography, Palaeoclimatology, Palaeoecology 53, 169-189.

Huber, B.T., Bralower, T.J., Leckie, R.M., 1999. Paleoecological and geochemical signatures of Cretaceous anoxic events: a tribute to William V. Sliter. Journal of Foraminiferal Research 29, 313-506.

Jarvis, I., Carson, G.A., Cooper, M.K.E., Hart, M.B., Leary, P.N., Tocher, B. A., Horne, D., Rosenfeld, A., 1988. Microfossils assemblages and the Cenomanian-Turonian (Late Cretaceous) oceanic anoxic event. Cretaceous Research 9, 3-103.

Jeans, C.V., Long, D., Hall, M.A., Bland, D.J., Cornford, C., 1991. The geochemistry of Plenus Marls at Dover, England: evidence of fluctuating oceanographic conditions and of glacial control during the development of the Cenomanian-Turonian $\delta^{13} \mathrm{C}$ anomaly. Geological Magazine 128, 603-632.

Jefferies, R., Milton, P., 1965. The mode of life of two Jurassic species of "Posidonia" (Bivalvia). Palaeontology 8, 156-185.

Jenkyns, H.C., Gale, A.S., Corfield, R.M., 1994. Carbon- and oxygen-isotope stratigraphy of the English Chalk and Italian Scaglia and its palaeoclimatic significance. Geological Magazine 131, 1-34.

Kauffman, E.G., Sageman, B.B., Kirkland, J.I., Elder, W.P., Harries, P.J., Villamil, I., 1993. Molluscan biostratigraphy of the Cretaceous Western Interior Basin, North America. In: Caldwell, W.G.E., Kauffman, E.G. (Eds.), Evolution of the Western Interior Basin. Geological Association of Canada, Special Paper 39. pp. 397-434.

Kennedy, W.J., Cobban, W.A., 1991. Stratigraphy and interregional correlation of the Cenomanian-Turonian transition in the Western Interior of the United States near Pueblo, Colorado. A potential boundary stratotype for the base of the Turonian stage. Newsletters in Stratigraphy 24, 1-33.

Kennedy, W.J., Cobban, W.A., Elder, W.P., Kirkland, J.I., 1999. Lower Turonian (Upper Cretaceous) Watinoceras devonense Zone ammonite fauna in Colorado, USA. Cretaceous Research 20, 629-639.

Kennedy, W.J., Walaszczyk, I., Cobban, W.A., 2000. Pueblo, Colorado, USA, candidate Global Boundary Stratotype Section and Point for the base of the Turonian Stage of the Cretaceous, and for the base of the Middle Turonian Substage, with a revision of the Inoceramidae (Bivalvia). Acta Geologia Polonica 50, 295-334.

Kennedy, W.J., Wright, C.W., Hancock, J.M., 1987. Basal Turonian ammonites from West Texas. Palaeontology 30, 27-74.

Leckie, R.M., 1985. Foraminifera of the Cenomanian-Turonian boundary interval, Greenhorn Formation, Rock Canyon Anticline, Pueblo Colorado. In: Pratt, L.M., Kauffman, E.G., Zelts, F.B. (Eds.), Fine-grained Deposits and Biofacies of the Cretaceous Western Interior Seaway: Evidence of Cyclic Sedimentary Processes. SEPM, 2nd Annual Meeting, Golden, CO, Field Trip Guide-book 4, pp. 139-149.

Leckie, R.M., Schmidt, M.G., Finkelstein, D., Yuretich, R., 1991. Paleoceanographic and paleoclimatic interpretations of the Mancos Shale (Upper Cretaceous), Black Mesa Basin, Arizona. In: Nations, J.D., Eaton, J.G. (Eds.), Stratigraphy, Depositional Environments, and Sedimentary Tectonics of the Western Margin, Cretaceous Western Interior Seaway. Geological Society of America Special Paper 260, pp. 139-152.

Leckie, R.M., Yuretrich, R.F., West, O.L.O., Finkelstein, D., Schmidt, M., 1998. Paleoceanography of the southwestern Western Interior Sea during the time of the Cenomanian-Turonian boundary (Late Cretaceous). In: Dean, W., Arthur, M.A. (Eds.), Stratigraphy and Paleoenvironments of the Cretaceous Western Interior Seaway. SEPM Concepts in Sedimentology and Paleontology 6, pp. 101-126.

Leithold, E., 1994. Stratigraphical architecture at the muddy margin of the Cretaceous Western Interior Seaway, southern Utah. Sedimentology 4, 521-542.

Longoria, J.F., 1973. Pseudoticinella, a new genus of planktonic foraminifera from the Early Turonian of Texas. Revista Española Micropaleontología 5, 417-423.

Luciani, V., Cobianchi, M., 1999. The Bonarelli Level and other black shales in the Cenomania-Turonian of the northeastern Dolomites (Italy): calcareous nannofossil and foraminiferal data. Cretaceous Research 20, 135-167.

Maamouri, A.I., Zaghbib-Turki, D., Matmati, M.F., Chikhaoui, M., Salaj, J., 1994. La Formation Bahloul en Tunisie centro-septentrionale : variations latérales, nouvelle datation et nouvelle interprétation en terme de stratigraphie séquentielle. Journal of African Earth Sciences 18, 37-50. 
MacArthur, R.H., Wilson, E.O., 1967. The Theory of Island Biogeography. Princeton University Press.

Meyers, S.R., Sageman, B.B., Hinnov, L., 2001. Integrated quantitative stratigraphy of the Cenomanian-Turonian Bridge Creek Limestone member using evolutive harmonic analysis and stratigraphic modeling. Journal of Sedimentary Research 71, 628-644.

Nederbragt, A.J., Fiorentino, A., 1999. Stratigraphy and palaeoceanography of the Cenomanian-Turonian Boundary Event in Oued Mellegue, north-western Tunisia. Cretaceous Research 20, 47-62.

Paul, C.R.C., Mitchell, S., Lamolda, M., Gorostidi, A., 1994. The Cenomanian-Turonian boundary event in northern Spain. Geological Magazine $131,801-817$

Peryt, D., Wyrwicka, K., 1991. The Cenomanian-Turonian oceanic anoxic event in SE Poland. Cretaceous Research 12, 65-80.

Pratt, L.M., 1982. A paleo-oceanographic interpretation of the sedimentary structures, clay minerals, and organic matter in a core of the Middle Cretaceous Greenhorn. Ph.D., Princeton University.

Pratt, L.M., 1984. Influence of paleoenvironmental factors on the preservation of organic matter in middle Cretaceous Greenhorn Formation near Pueblo, Colorado. American Association of Petroleum Geologists, Bulletin 68, $1146-1159$.

Pratt, L.M., 1985. Isotopic studies of organic and carbonate in rocks of the Greenhorn marine cycles. In: Pratt, L.M., Kauffman, E.G., Zelt, F.B. (Eds.), Fine-Grained Deposits and Biofacies of the Cretaceous Western Interior Seaway: Evidence of cyclic Sedimentary Processes. SEPM, 2nd Annual Meeting Golden, CO, Field Trip Guidebook 4, pp. 38-48.

Pratt, L.M., Arthur, M.A., Dean, W.E., Scholle, P.A., 1993. Paleoceanographic cycles and events during the Late Cretaceous in the Western Interior Seaway of North America. In: Caldwell, W.G.E., Kauffman, E.D. (Eds.), Evolution of the Western Interior Basin. Geological Association of Canada, Special Paper 39, pp. 333-354.

Pratt, L.M., Kaufman, E.G., Zelt, F.B., 1985. Fine-Grained Deposits and Biofacies of the Cretaceous Western Interior Seaway: Evidence of cyclic Sedimentary Processes. SEPM, 2nd Annual Meeting Golden, CO, Field Trip Guidebook 4 1-249.

Pratt, L.M., Threlkeld, C.N., 1984. Stratigraphic significance of ${ }^{13} \mathrm{C} /{ }^{12} \mathrm{C}$ ratios in Mid-Cretaceous rocks of the Western Interior, USA. Canadian Society of Petroleum Geologists, Memoir 9, 305-312.

Ricken, W., 1993. Variation of sedimentation rates in rhythmically bedded sediments. Distinction between depositional types. In: Einsele, G., Ricken, W., Seilacher, A. (Eds.), Cycles and events in Stratigraphy. Springer-Verlag, Berlin, pp. 1-955.

Robaszynski, F., Caron, M., 1995. Foraminifères planctoniques du Crétacé : commentaire de la zonation Europe-Méditerranée. Bulletin de la Société géologique de France 166, 681-692.

Robaszynski, F., Caron, M., Amédro, F., Dupuis, C., Hardenbol, J., GonzalezDonoso, J.M., Linares, D., Gartner, S., 1993a. Le Cénomanien de la région de Kalaat Senan (Tunisie Centrale): Litho-biostratigraphie et interprétation séquentielle. Revue de Paléobiologie 12, 351-505.

Robaszynski, F., Caron, M., Dupuis, C., Amédro, F., Gonzalez-Donoso, J.M., Linares, D., Hardenbol, J., Gartner, S., Calandra, F., Deloffre, R., 1990. A tentative integrated stratigraphy in the Turonian of Central Tunisia: formations, zones and sequential stratigraphy in the Kalaat Senan area. Bulletin des Centres de Recherches Exploration-Production Elf Aquitaine 14, $213-$ 384.

Robaszynski, F., Caron, M., 1979. European Working Group on Planktonic Foraminifera. Atlas of Mid Cretaceous Planktonic Foraminifera. Cahiers de Micropaléontologie 1 1-185.

Robaszynski, F., Hardenbol, J., Caron, M., Amédro, F., Dupuis, C., Gonzalez Donoso, J.M., Linares, D., Gartner, S., 1993b. Sequence stratigraphy in a distal environment: the Cenomanian of the Kalaat Senan region of Central Tunisia. Bulletin des Centres de Recherches Exploration-Production Elf Aquitaine 17, 395-433.

Sageman, B.B., Rich, J., Arthur, M.A., Birchfield, G.E., Dean, W.E., 1997. Evidence for Milankovitch periodicities in Cenomanian-Turonian lithologic and geochemical cycles, Western Interior, USA. Journal of Sedimentary Research 672, 286-302.

Sageman, B.B., Rich, J., Arthur, M.A., Dean, W.E., Savrda, C.E., Bralower, T. J., 1998. Multiple Milankovitch cycles in the Bridge Creek Limestone (Cenomanian-Turonian), Western Interior Basin. SEPM, Concepts in Sedimentology and Paleontology 6, 153-171.

Savrda, C.A., 1998. Ichnology of the Bridge Creek Limestone: evidence for temporal and spatial variations in paleo-oxygenation in the Western Interior seaway. SEPM, Concepts in Sedimentology and Paleontology 6, 137-151.

Sigal, J., 1977. Essai de zonation du Crétacé méditerranéen à l'aide des foraminifères planctoniques. Géologie Méditerranéenne 4, 99-108.

Schlanger, S.O., Jenkyns, H.C., 1976. Cretaceous oceanic anoxic events, causes and consequences. Geologie en Mijnbouw 55, 179-184.

Schlanger, S.O., Arthur, M.A., Jenkyns, H.C., Scholle, P.A., 1987. The Cenomanian-Turonian oceanic event. I; Stratigraphy and distribution of organic carbon-rich beds and the marine $\delta^{13} \mathrm{C}$ excursion. In: Brooks, J., Fleet, A.J. (Eds.), Marine petroleum source rocks. Geological Society of London, Special Publication 26. pp. 371-399.

Scholle, P.A., Arthur, M.A., 1980. Carbon isotope fluctuations in Cretaceous pelagic limestone: potential stratigraphic and petroleum exploration tool. American Association of Petroleum Geologists, Bulletin 64, 67-87.

Ulicny, D., Hladikova, J., Attrep Jr., M.J., Cech, S., Hradecka, L., Svobodova, M., 1997. Sea-level changes and geochemical anomalies across the Cenomanian-Turonian boundary, Pecinov quarry, Bohemia. Palaeogeography, Palaeoclimatology, Palaeoecology 132, 265-285.

West, O.L., Leckie, M., Schmidt, M., 1998. Foraminiferal paleoecology and paleoceanography of the Greenhorn cycle along the southwestern margin of the Western Interior sea. SEPM, Concepts in Sedimentology and Paleontology 6, 79-99.

Wonders, A.A.H., 1980. Middle and late Cretaceous planktonic foraminifera of the Western Mediterranean area. Utrecht Micropaleontological Bulletin $24,1-136$.

Wright, C.W., Kennedy, W.J., 1981. The Ammonoidea of the Plenus Marls and the Middle Chalk. Palaeontographical Society (Monograph of), London 560 [part of Vol. 134 for 1980], 1-148. 